\title{
Micrometeorological conditions and surface mass and energy fluxes on Lewis Glacier, Mt Kenya, in relation to other tropical glaciers
}

\author{
L. I. Nicholson ${ }^{1}$, R. Prinz ${ }^{1,2}$, T. Mölg ${ }^{3}$, and G. Kaser ${ }^{1}$ \\ ${ }^{1}$ Center for Climate and Cryosphere, Institute for Meteorology and Geophysics, University of Innsbruck, Innrain 52, 6020 \\ Innsbruck, Austria \\ ${ }^{2}$ ENVEO IT GmbH, Technikerstraße 21a, 6020 Innsbruck, Austria \\ ${ }^{3}$ Chair of Climatology, Technische Universität Berlin, Rothenburgstraße 12, 12165 Berlin, Germany
}

Correspondence to: L. I. Nicholson (lindsey.nicholson@uibk.ac.at)

Received: 6 November 2012 - Published in The Cryosphere Discuss.: 14 December 2012

Revised: 20 June 2013 - Accepted: 28 June 2013 - Published: 5 August 2013

\begin{abstract}
The Lewis Glacier on Mt Kenya is one of the beststudied tropical glaciers, but full understanding of the interaction of the glacier mass balance and its climatic drivers has been hampered by a lack of long-term meteorological data. Here we present $2.5 \mathrm{yr}$ of meteorological data collected from the glacier surface from October 2009 to February 2012. The location of measurements is in the upper portion of Lewis Glacier, but this location experiences negative annual mass balance, and the conditions are comparable to those experienced in the lower ablation zones of South American glaciers in the inner tropics. In the context of other glaciated mountains of equatorial East Africa, the summit zone of Mt Kenya shows strong diurnal cycles of convective cloud development as opposed to the Rwenzoris, where cloud cover persists throughout the diurnal cycle, and Kilimanjaro, where clear skies prevail. Surface energy fluxes were calculated for the meteorological station site using a physical mass- and energy-balance model driven by measured meteorological data and additional input parameters that were determined by Monte Carlo optimization. Sublimation rate was lower than those reported on other tropical glaciers, and melt rate was high throughout the year, with the glacier surface reaching the melting point on an almost daily basis. Surface mass balance is influenced by both solid precipitation and air temperature, with radiation providing the greatest net source of energy to the surface. Cloud cover typically reduces the net radiation balance compared to clear-sky conditions, and thus the frequent formation of convective clouds over the summit of Mt Kenya and the associated higher rate of snow accumulation are important in limiting the rate of mass loss from
\end{abstract}

the glacier surface. The analyses shown here form the basis for future glacier-wide mass and energy balance modeling to determine the climate proxy offered by the glaciers of $\mathrm{Mt}$ Kenya.

\section{Introduction}

Tropical glaciers have proven potential to give information about conditions in the poorly sampled tropical midtroposphere over annual to centennial timescales, provided both their interaction with the atmosphere (e.g., Hastenrath, 1984; Osmaston, 1989; Kaser and Georges, 1999; Kaser, 2001; Kaser and Osmaston, 2002; Mölg and Hardy, 2004) and their relationship to regional and synoptic-scale climate dynamics (e.g., Mölg et al., 2003a, b, 2006a, 2009a, b; Kaser et al., 2004; Francou et al., 2004; Vuille et al., 2008) are understood. Such information can serve to help examine ideas about recent changes in tropical circulation and their impact on regional and global climate (e.g., Held and Soden, 2006; Lyon and DeWitt, 2012).

Meteorological conditions in equatorial East Africa result from complex interactions between multiple convergence zones and topographic, marine and lacustrine influences (Nicholson, 1996). The annual climate cycle is dominated by bimodal precipitation seasonality, consisting of the "long rains" (March to May (MAM)) and the "short rains" (October to December (OND)) and driven by the passage of the tropical rainfall belt associated with the Intertropical Convergence Zone (ITCZ). The western Indian Ocean 


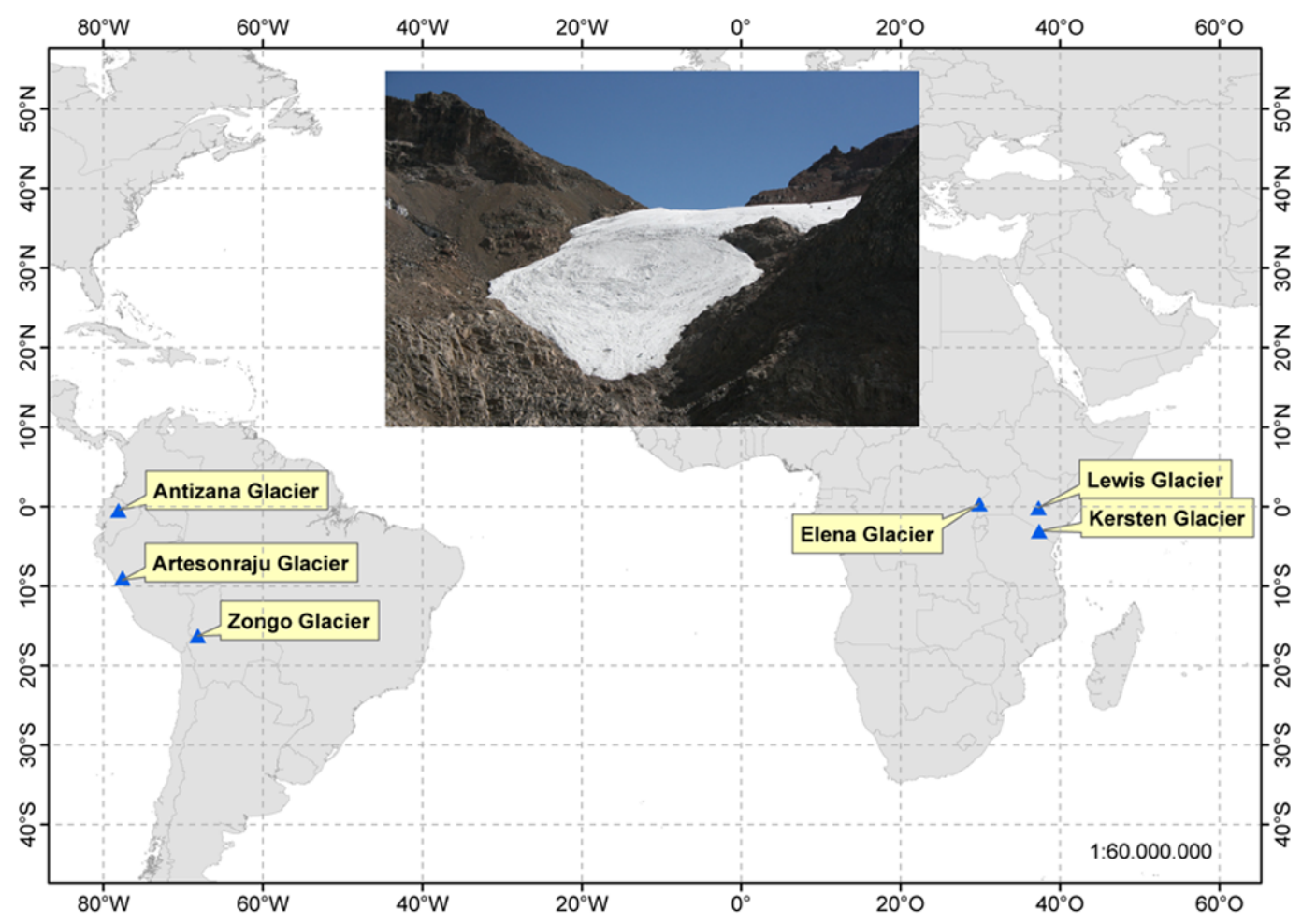

Fig. 1. Location map of the tropical glacier sites referred to in this study, with an inset showing Lewis Glacier in February 2012 (photo credit: Stephan Galos).

is the dominant moisture source for equatorial East Africa, supplemented by convergent eastward-traveling convective waves crossing the continent (e.g., Whittow, 1960; Sun et al., 1999; Mpeta and Just, 2001; Chan et al., 2008) and by incursions of moist air from the Congo Basin (e.g., Sun et al., 1999; Pohl and Camberlin, 2006). During the short rains, enhanced moisture and precipitation anomalies have been associated with positive phases of both (i) El Niño Southern Oscillation (ENSO), which causes higher sea surface temperatures in the Indian Ocean and consequently enhanced convection and evaporation (Mutai and Ward, 2000), and (ii) the Indian Ocean Zonal Mode, which accentuates the Indian Ocean trade winds and onshore moisture transport to equatorial East Africa (Hastenrath, 2000, Chan et al., 2008, Mölg et al., 2006a, 2009b). Relationships between interannual variation in the long rains and large-scale climate modes are not as well established, but decline of the long rains over recent decades has been linked to warming of the tropical Indian Ocean and westward extension of the Walker cell that tends to suppress convective activity over equatorial East Africa (Funk et al., 2008; Williams and Funk, 2011).

Three glacierized areas remain in equatorial East Africa (Fig. 1): Kilimanjaro [ $\left.3^{\circ} 04^{\prime} \mathrm{S}, 37^{\circ} 21^{\prime} \mathrm{E} ; 5895 \mathrm{~m}\right]$, Mt Kenya $\left[0^{\circ} 09^{\prime} \mathrm{S}, 37^{\circ} 18^{\prime} \mathrm{E} ; 5199 \mathrm{~m}\right]$ and the Rwenzori Range $\left[0^{\circ} 23^{\prime} \mathrm{N}, 29^{\circ} 52^{\prime} \mathrm{E} ; 5109 \mathrm{~m}\right]$, and all of these regions have shown strong glacier retreat over the 20th century (Cullen et al., 2006; Prinz et al., 2011; Kaser and Osmaston, 2002; Cullen et al., 2013). The Lewis Glacier (LG) on Mt Kenya has abundant historical glaciological data and is also the only benchmark tropical glacier outside of South America (WGMS, 2008). Thus, despite its small size, LG remains an important glacier to understand in the context of both global glacier changes and the climatic changes recorded by tropical glaciers. The geodetic mass balance of LG spanning 1934-2010 has been determined from field maps (Prinz et al., 2011), and, within this period, $20 \mathrm{yr}$ of detailed annual mass balance data have been compiled for the mass balance years of 1979-1996 (Hastenrath, 2005) and 2011-2012 (Prinz et al., 2012). Where concurrent data are available the geodetic and glaciological measurements of mass balance are within error of each other. Between 1934 and 2010 Lewis Glacier lost $16.67 \pm 3.82 \times 10^{6} \mathrm{~m}^{3}(90 \%)$ of its 1934 volume and $0.394 \pm 0.015 \times 10^{6} \mathrm{~m}^{3}(79 \%)$ of its 1934 surface area (Prinz et al., 2011). Mean specific mass balance rate between 1934 and 1974 ranged between $-0.22 \pm 0.40$ and $-0.54 \pm 0.63 \mathrm{~m}$ w.e. $\mathrm{a}^{-1}$, after which mass balance became more negative, and was mostly negative between 1993 and 2004, when mean specific mass balance rate was $-2.22 \pm 0.44 \mathrm{~m}$ w.e. $\mathrm{a}^{-1}$ (Prinz et al., 2011), and the most recent glaciological measurements of annual mass balance are $-1.40,-1.54$ and $-1.03 \mathrm{~m}$ w.e. for the mass balance years 2009/10, 2010/11 and 2011/12, respectively 
(Prinz et al., 2011, 2012). Although periods of a few days measurements of some meteorological variables exist from April 1960, July to August 1975 and February to March 1978 (Platt, 1966; Davies et al., 1977; Hastenrath and Patnaik, 1980; Hastenrath, 1983), no previous meteorological or surface energy balance (SEB) measurements over annual timescales that would enable full assessment of the climatic drivers of glacier recession have been carried out.

Past studies have attributed recession of equatorial East African glaciers to various changes in climatic conditions (Kaser and Noggler, 1991; Hastenrath and Kruss, 1992; Thompson et al., 2002; Mölg et al. 2003a, b, 2006a; Kaser et al., 2004; Hastenrath 2010). However, recent process-based assessments have determined the primary driver of retreat of slope glaciers on Kilimanjaro to be decreasing atmospheric moisture since the end of the late 19th century (Mölg et al., 2009a). On Kilimanjaro, declining atmospheric moisture, which has reduced summit precipitation and hence glacier accumulation, has been linked to a decrease in the frequency of the Indian Ocean Zonal Mode (Mölg et al., 2006a). Concordant decreases in atmospheric longwave and sensible heat fluxes to the surface are largely compensated for by increases in absorbed solar radiation, due to reduced cloud cover and lower surface albedo, such that energy-driven mass losses remain comparable to those in more humid conditions and consequently retreat in glaciers on Kilimanjaro is driven by the precipitation deficit (Mölg et al., 2009a). In contrast to this energy balance response on Kilimanjaro, studies show that on South American tropical glaciers, reduced atmospheric moisture reduces accumulation, and ablation can either be enhanced, through the albedo feedback in which reduced precipitation results in decreased albedo and enhanced absorption of solar radiation, or reduced, as a result of (i) diverting energy from melting to the energetically more expensive ablation process of sublimation, and (ii) reducing incoming longwave radiation (Wagnon et al., 1999; Francou et al., 2003; Winkler at al., 2009). The mass balance variability of the South American tropical glaciers is influenced by ENSO, with El Niño events resulting in more negative mass balance: in the inner tropics, higher temperatures during El Niño increase ablation and also mean that a higher proportion of precipitation on the glacier surface is liquid rather than solid, while in the outer tropics, El Niño events are associated with reduced precipitation as well as higher temperatures (Wagnon et al., 2001; Favier et al., 2004a; Francou et al., 2003, Vuille et al., 2008). Evidently, the impact of a changing climate on the surface energy and mass balance of tropical glaciers is strongly dependent on the prevailing climate conditions and processes at their locations, as well as the regionally active climate modes. As glaciers on Mt Kenya and the Rwenzoris are much closer to the long-term (19772007) regional freezing level of $\sim 4650-4750 \mathrm{~m}$ (Bradley et al., 2009) than the slope glaciers of Kilimanjaro (Cullen et al., 2006), heat transfer from the warmer atmosphere is expected to play a key role in the energy and mass balance of these lower elevation glaciers, in contrast to the glaciers on Kilimanjaro, which show a very weak energy and mass balance response to any changes in atmospheric temperature (Mölg et al., 2009a).

Detailed surface energy balance studies are needed to determine what climate signals are potentially reflected in changes of equatorial East African glaciers near the regional freezing level, and how these relate to the climate proxy offered by glaciers on Kilimanjaro and in tropical South America. To this end, this paper presents meteorological conditions recorded by an automatic weather station (AWS) installed on Lewis Glacier in September 2009 and characteristics of the surface energy balance at the site in the context of available data from other key tropical glacier sites.

\section{Data and methodology}

\subsection{Measurement sites and meteorological data}

Lewis Glacier $\left(0.1 \mathrm{~km}^{2}\right)$ lies $\sim 370 \mathrm{~m}$ below the summit of Mt Kenya in a quasi-cirque location between the true summit and a secondary peak (inset Fig. 1). The AWS at $4828 \mathrm{~m}$ elevation is $\sim 40 \mathrm{~m}$ below the upper limit of the glacier. Data are available from 26 September 2009 to 22 February 2012. However, there is a gap in the surface height and wind direction records from 25 January to 2 March 2010 because the mast was rotating, and a gap in all records from 20 July to 29 September 2010 because the AWS mast broke. Thus, 773 days of complete data in three separate periods are available for analysis. All instruments on the AWS (Table 1) are naturally ventilated and measured every $1 \mathrm{~min}$, and half-hourly averages are stored on a Campbell Scientific CR3000 datalogger.

Naturally ventilated air temperature measurements can suffer from radiative heating when insolation is high and wind speed is low and the sensor shielding is inadequate (e.g., Georges and Kaser, 2002), and in the case of combined temperature and relative humidity sensors, the membrane that protects the sensors from contamination further impedes natural ventilation. The Met21 radiation shield used at LG combines white outer lamina and black inner louvres that prevent direct solar radiation reaching the sensor from any direction. The manufacturers specification reports that comparative studies between this type of radiation shield and an aspirated sensor indicate that at wind speeds $<1 \mathrm{~m} \mathrm{~s}^{-1}$ with intense solar radiation, measured air temperature can be $0.5^{\circ} \mathrm{C}$ above that recorded by an artificially ventilated sensor. At LG, times with low wind speed coincide with overcast skies, and so in the absence of concurrent ventilated temperature and humidity measurements required to explicitly evaluate any impact of radiative heating on the sensor, we have assumed that the radiation shielding is adequate. Comparison of the $2{ }^{\circ} \mathrm{C}$-binned hourly air temperature $(T)$ from the Vaisala sensor with that of a Campbell Scientific 107 
Table 1. Details of the Lewis Glacier automatic weather station instrumentation and symbols used to refer to meteorological variables. Secondary air temperature measurements were made with a Campbell Scientific 107 thermistor.

\begin{tabular}{lllll}
\hline variable & symbol (unit) & instrument & initial height (m) & stated accuracy \\
\hline air temperature & $T\left({ }^{\circ} \mathrm{C}\right)$ & Vaisala HMP45C with & 1.50 & $\pm 0.3^{\circ} \mathrm{C}$ at $0{ }^{\circ} \mathrm{C}$ \\
& & Met21 radiation shield & \\
relative humidity & $\mathrm{RH}(\%)$ & Vaisala HMP45C & 1.50 & $\pm 3 \%$ at $20^{\circ} \mathrm{C}$ \\
radiation fluxes & $\mathrm{SWI}, \mathrm{SWO}, \mathrm{LWI}, \mathrm{LWO}\left(\mathrm{W} \mathrm{m}^{-2}\right)$ & Kipp \& Zonen CNR-4 & 1.50 & $\pm 10 \%$ day total \\
wind speed wind direction & $V\left(\mathrm{~m} \mathrm{~s}^{-1}\right) \mathrm{DIR}\left({ }^{\circ}\right)$ & Young 05103 & 2.51 & $\pm 0.3 \mathrm{~m} \mathrm{~s}$ \\
& & anemometer & \\
air pressure & $P(\mathrm{hPa})$ & Setra 278 & & $\pm 1.5 \mathrm{hPa}$ \\
surface height & $\mathrm{SFC}(\mathrm{m})$ & Campbell Scientific & 1.76 & $\pm 0.01 \mathrm{~m}$ \\
& & SR50a sonic ranger & & \\
\hline
\end{tabular}

Radiation fluxes: SWI: shortwave incoming, SWO: shortwave outgoing, LWI: longwave incoming, LWO: longwave outgoing.

thermistor installed within the same radiation shield (Mölg et al., 2008) indicates that differences between the two sensors exceed the error margins of the sensors in only $0.02 \%$ cases, so measured temperatures appear unaffected by the sensor membrane. Reported relative humidity $(\mathrm{RH})$ values have been rescaled to give RH with respect to water or ice, dependent on ambient air temperature, and truncated at $100 \%$ (Anderson, 1994). Vapor pressure (e) and specific humidity ( $q$ ) were computed using Magnus-Tetens formulae (Murray, 1967). Nocturnal values of SWI and SWO were set to 0, as were all value pairs for which $\mathrm{SWI}<1 \mathrm{Wm}^{-2}$. At high elevation sites such as this, measured SWO can be higher than SWI when solar zenith angle is high. Outside of these hours SWO $>$ SWI was taken to indicate snow cover or riming on the upper sensor and in these cases ( $0.6 \%$ of the data) measured SWI was replaced with SWO divided by the typical snow albedo over the measurement period. Daily albedo values $\left(\alpha_{\text {day }}\right)$ were computed as the ratio of daily total SWO to daily total SWI for the whole day (Oerlemans and Knap, 1998; Van den Broeke et al., 2008) without any geometrical corrections, as twice yearly visits to the AWS indicated that the sensors remained level throughout the measurement period. Gaps in the wind speed $(V)$ record caused by occasional freezing of the anemometer ( $0.1 \%$ of the data) were filled by linear interpolation between the hourly values of adjacent days. Daily snow accumulation height was computed as positive surface changes between successive midnight surfaces, taken as the mean of half-hourly measurements from 22:00 to 02:00 inclusive, which minimizes noise contamination of the signal. This approach might under-represent accumulation if snowfall in a given day is subject to significant ablation or compaction within the same day. Mean midnight surfaces for which the standard deviation was greater than the 90th percentile were replaced with linear interpolation between adjacent days. Clear-sky days were identified as those with parabolic diurnal cycles of SWI, and comparison of the total daily SWI on these days with daily total top of atmosphere radiation (TOA) provided threshold levels to identify clear-sky days, which were defined at LG as those for which daily SWI $>75 \%$ of daily TOA. Completely overcast conditions during daylight hours were defined as times when measured SWI was $<35 \%$ of the theoretical clearsky SWI (Hastenrath, 1984; Mölg et al., 2009c), which was calculated for mean conditions using the equations given in Mölg et al. (2009c).

Published data from four other tropical glaciers, plus one non-glacier station, are used to provide context for the conditions measured on LG (Fig. 1). These sites are (1) an offglacier station located $50 \mathrm{~m}$ below the Elena Glacier (EG) on Mt Stanley in the Rwenzori range of Uganda (Lentini et al., 2011); (2) the uppermost reaches of Kersten Glacier (KG) on Kilimanjaro, Tanzania (Mölg et al., 2008, 2009a); (3) the ablation zone of Antisana 15 Glacier (AG) in Antisana, Ecuador (Favier et al., 2004a, b); (4) the ablation zone of Artesonraju Glacier (ARG) in the Cordillera Blanca of Peru (Juen, 2006); and (5) the ablation zone of Zongo Glacier (ZG) in the Cordillera Real of Bolivia (Favier et al., 2004a; Sicart et al., 2005). The periods of data assessed in these publications do not coincide, and some consider only one year from a longer record (see Table 2), but assessments of their representativeness for typical conditions are given in the respective publications. The first three sites are, like LG, all in the inner tropics, while the last two sites, ARG and ZG, are located in the outer tropics and are included for broader context only.For KG, additional unpublished data are available up to October 2011, which allows comparison of meteorological conditions at LG and KG over a period of concurrent measurements (PCM) spanning 1 October 2009 to 19 July 2010.

\subsection{Additional climatological data}

The representativeness of the measurement period at LG in the context of regional precipitation seasonality was assessed in the context of the 1998-2012 monthly mean $0.5^{\circ}$ TRMM 3B43.V7 precipitation rate (i) averaged over a domain encompassing both Mt Kenya and Kilimanjaro (-5.0 to $2.5^{\circ} \mathrm{N}$, 35 to $40^{\circ} \mathrm{E}$ ), and (ii) at the closest grid point to Mt Kenya 
Table 2. Comparison of the AWS station locations and daily mean (standard deviation) conditions measured at each site over the respective period of published data. ARG and ZG are glaciers in the outer tropics.

\begin{tabular}{|c|c|c|c|c|c|c|}
\hline & \multicolumn{3}{|c|}{ East African sites } & \multicolumn{3}{|c|}{ South American sites } \\
\hline & LG & EG & KG & $\mathrm{AG}$ & ARG & $\mathrm{ZG}$ \\
\hline source & this study & Lentini et al. (2011) & $\begin{array}{l}\text { Mölg et al. } \\
(2009 a)\end{array}$ & $\begin{array}{l}\text { Favier et al. } \\
(2004 b)\end{array}$ & Juen (2006) & $\begin{array}{l}\text { Favier et al. } \\
(2004 a)\end{array}$ \\
\hline ma.s.l. & 4828 & 4750 & 5873 & 4890 & 4850 & 5050 \\
\hline coordinates & $0^{\circ} 09^{\prime} \mathrm{S}$ & $0^{\circ} 22^{\prime} \mathrm{N}$ & $3^{\circ} 04^{\prime} \mathrm{S}$ & $0^{\circ} 28^{\prime}$ & $8^{\circ} 57^{\prime} \mathrm{S}$ & $16^{\circ} 15^{\prime} \mathrm{S}$ \\
\hline & $37^{\circ} 18^{\prime} \mathrm{E}$ & $29^{\circ} 52^{\prime} \mathrm{E}$ & $37^{\circ} 21^{\prime} \mathrm{E}$ & $78^{\circ} 09^{\prime} \mathrm{W}$ & $77.38^{\prime} \mathrm{W}$ & $68^{\circ} 10^{\prime} \mathrm{W}$ \\
\hline location & $\begin{array}{l}\text { upper glacier } \\
\text { inner tropics }\end{array}$ & $\begin{array}{l}\text { off glacier } \\
\text { inner tropics }\end{array}$ & $\begin{array}{l}\text { upper glacier } \\
\text { inner tropics }\end{array}$ & $\begin{array}{l}\text { lower glacier } \\
\text { inner tropics }\end{array}$ & $\begin{array}{l}\text { lower glacier } \\
\text { outer tropics }\end{array}$ & $\begin{array}{l}\text { lower glacier } \\
\text { outer tropics }\end{array}$ \\
\hline sky view & $88 \%$ & - & $98 \%$ & $95 \%$ & & $94 \%$ \\
\hline date range & 09/09-07/10 & $10 / 06-08 / 07$ & 02/05-01/08 & 03/02-03/03 & 04/04-04/05 & 08/99-08/00 \\
\hline & 09/10-02/12 & 07/08-06/09 & & & & \\
\hline$[\mathrm{mm} / \mathrm{yy}]$ & $\begin{array}{l}36 \text { days } \\
\text { missing }\end{array}$ & $\begin{array}{l}8 \% \text { data } \\
\text { missing }\end{array}$ & $\begin{array}{l}\text { no data } \\
\text { missing }\end{array}$ & $\begin{array}{l}16 \text { days } \\
\text { missing }\end{array}$ & & \\
\hline$T\left[{ }^{\circ} \mathrm{C}\right]$ & $-0.9(0.8)$ & $-0.35(0.8)$ & $-6.8(1.1)$ & $0.3(0.7)$ & $0.7(0.8)$ & $-0.8(1.4)$ \\
\hline$T$ ice $\left[{ }^{\circ} \mathrm{C}\right]$ & $-2.9(1.6)$ & - & $-8.9(2.1)$ & $-1.4(0.7)$ & & $-3.1(2.1)$ \\
\hline $\mathrm{RH}[\%]$ & $75(19)$ & $90(9)$ & $56(26)$ & $81(11)$ & & $71(21)$ \\
\hline $\mathrm{q}\left[\mathrm{g} \mathrm{kg}^{-1}\right]$ & $4.7(1.3)$ & - & $2.6(1.2)$ & $5.5(0.7)$ & $4.8(5.1)$ & $4.7(1.5)$ \\
\hline$V\left[\mathrm{~m} \mathrm{~s}^{-1}\right]$ & $2.8(1.0)$ & $3.6(2.3)$ & $4.8(2.5)$ & $4.8(3.5)$ & $3.2(2.8)$ & $2.7(1.2)$ \\
\hline SWI [W m ${ }^{-2}$ ] & $191(65)$ & $121(49)$ & $339(58)$ & $239(68)$ & $230(64)$ & $209(61)$ \\
\hline $\mathrm{LWI}\left[\mathrm{W} \mathrm{m}^{-2}\right]$ & $255(33)$ & - & $179(44)$ & $272(29)$ & $281(34)$ & $258(45)$ \\
\hline albedo & $0.56(0.17)$ & - & $0.56(0.13)$ & $0.49(0.18)$ & $0.54(0.18)$ & $0.66(0.18)$ \\
\hline snow $\left[\mathrm{mm}\right.$ w.e. $\left.\mathrm{d}^{-1}\right]$ & $2.94^{\mathrm{a}}$ & $4.00^{\mathrm{b}}$ & $1.36^{\mathrm{a}}$ & 1.95 & & \\
\hline$P[\mathrm{hPa}]$ & $571(0.9)$ & $581(0.7)$ & $501(0.7)$ & - & & - \\
\hline
\end{tabular}

a Computed from daily snow depth accumulation multiplied by the 90th percentile density of fresh snow from all available field measurements which was $420 \mathrm{~g} \mathrm{~kg}^{-1}$ at $\mathrm{LG}_{\text {and }}$ $255 \mathrm{~g} \mathrm{~kg}^{-1}$ at KG. ${ }^{\mathrm{b}}$ Is not solid precipitation accumulation but total precipitation in mm w.e.

$\left(37^{\circ} \mathrm{E}, 0^{\circ} \mathrm{N}\right)$. Time series of the data were generated using the Giovanni online data system, developed by the NASA Goddard Earth Sciences Data and Information Services Centre (http://disc.sci.gsfc.nasa.gov/giovanni/), and monthly anomalies from the mean annual cycle were computed for the period of measurements at LG AWS. Similarly, the representativeness of the measurement period in terms of air temperature was assessed on the basis of the European Centre for Medium-Range Weather Forecasts (ECMWF) ERAInterim reanalysis data (http://data-portal.ecmwf.int/data/d/ interim_mnth/), for which monthly anomalies in $500 \mathrm{hPa}$ level air temperature averaged over 36.5 to $38.5^{\circ} \mathrm{E}$ and -1 to $1^{\circ} \mathrm{N}$ during the measurement period were computed in relation to the mean annual cycle for 1979-2012.

To ascertain whether Mt Kenya and Kilimanjaro were influenced by different air masses during the PCM, monthly mean ERA-Interim wind fields, covering the region of the two mountains $\left(35-40.0^{\circ} \mathrm{E}\right.$ and $\left.6^{\circ} \mathrm{S}-3^{\circ} \mathrm{N}\right)$, at $10 \mathrm{~m}$ above the model surface and at the $500 \mathrm{hPa}$ level were examined. However, since these data represent only mean conditions, 5-day back trajectories were computed for (i) the summit coordinates of Mt Kenya and Kilimanjaro, (ii) the horizontal coordinates of each summit at the elevation of the model surface, and (iii) at $200 \mathrm{hPa}$. The back trajectories were calculated for the target location at 12:00 UTC (15:00 LT) for all days in the PCM using the online METEX tool (Zeng et al., 2010 ), with the $0.5^{\circ}$-spatial and 6-hourly-temporal resolu- tion Japanese Meteorological Agency Global Spectral Model forecast output.

\subsection{Surface energy and mass balance model}

The meteorological data from LG are used to drive a processbased mass and surface energy balance model (Mölg et al., 2008, 2009a, 2012) at the AWS location. The model is driven by hourly mean AWS inputs of $T$, SWI, $\alpha_{\text {day }}$, LWI, RH, surface pressure $(P), V$ and snow accumulation rate, since both historical (Hastenrath, 1984) and our recent observations suggest all precipitation is solid at LG. Daily snow accumulation height is converted to accumulated mass using a parameterized value for fresh snow density, and the daily mass accumulation is divided through all hours of the day in which $\mathrm{RH}>90 \%$. The model solves the SEB at hourly timesteps, including a subsurface module with 14 levels over a depth of $3 \mathrm{~m}$ that computes the heat flux and resultant temperature distribution in the glacier body. The energy fluxes and temperature field are then used to determine mass fluxes of surface and subsurface melt, sublimation, deposition and refreezing in the snow pack at each timestep, resulting in a modeled surface height change.

Following Mölg et al. (2012), model parameters (Table 3) were optimized using a Monte Carlo approach, in which, for each of the three periods of available data, 1000 realizations of the model were performed with random parameter values generated to span the physically meaningful range 
Table 3. Mass and energy balance model input parameters that were determined by Monte Carlo optimization, showing the permissible value range and source of constraining data, and the mass balance response to perturbing individual parameters to the maximum and minimum of their permissible range.

\begin{tabular}{|c|c|c|c|c|}
\hline parameter & unit & range & source and notes & mass balance sensitivity \\
\hline $\begin{array}{l}\text { penetration depth of } \\
\text { daily temperature cycle }\end{array}$ & $\mathrm{m}$ & $0.5 \pm 20 \%$ & $\begin{array}{l}\text { Determined through diffusion experi- } \\
\text { ment driven with LWO-derived surface } \\
\text { temperature }\end{array}$ & $\pm 20 \%$ \\
\hline z0 ice & $\mathrm{m}$ & $15 \times 10^{-3} \pm 5 \times 10^{-3}$ & $\begin{array}{l}\text { Winkler et al. (2009). Value is larger } \\
\text { than that found for melting midlati- } \\
\text { tude ice surfaces as small penitents have } \\
\text { been observed at LG. }\end{array}$ & $\pm 1 \%$ \\
\hline $\mathrm{z} 0$ fresh snow & $\mathrm{m}$ & $0.5 \times 10^{-3} \pm 0.4 \times 10^{-3}$ & Brock et al. (2006). & $\pm 1 \%$ \\
\hline z0 old snow & $\mathrm{m}$ & $4.5 \times 10^{-3} \pm 3.5 \times 10^{-3}$ & Brock et al. (2006). & $\pm 1 \%$ \\
\hline density of fresh snow & $\mathrm{g} \mathrm{kg}^{-1}$ & $370 \pm 60$ & $\begin{array}{l}\text { Field measurements of fresh snow span } \\
330 \text { to } 430 \mathrm{~kg} \mathrm{~m}^{-3} \text {. }\end{array}$ & $\pm 12 \%$ \\
\hline $\begin{array}{l}\text { bulk density of snow } \\
\text { pack at beginning of } \\
\text { run }\end{array}$ & $\mathrm{g} \mathrm{kg}^{-1}$ & $500 \pm 20 \%$ & $\begin{array}{l}\text { Field measurements of aged snow } \\
\text { span } 430 \text { to } 510 \mathrm{~kg} \mathrm{~m}^{-3} \text {. In previous } \\
\text { mass balance work on LG, bulk snow } \\
\text { density was taken to be } 600 \mathrm{~kg} \mathrm{~m}^{-3} \\
\text { (Hastenrath, 1984). }\end{array}$ & $< \pm 1 \%$ \\
\hline $\begin{array}{l}\text { fraction of refreezing } \\
\text { meltwater forming su- } \\
\text { perimposed ice }\end{array}$ & & $0.3 \pm 20 \%$ & Mölg et al. (2009a). & $< \pm 1 \%$ \\
\hline $\begin{array}{l}\% \text { of SWI penetrating } \\
\text { ice/snow }\end{array}$ & $\%$ & $20 \pm 20 \% / 10 \pm 10 \%$ & $\begin{array}{l}\text { Bintjana and Van den Broeke (1995), } \\
\text { Mölg et al. (2008). }\end{array}$ & $\pm 3 \% / \pm 4 \%$ \\
\hline $\begin{array}{l}\text { extinction coefficient of } \\
\text { SWI in ice/snow }\end{array}$ & $\mathrm{m}^{-1}$ & $2.5 \pm 20 \% / 17.1 \pm 20 \%$ & $\begin{array}{l}\text { Bintjana and Van den Broeke (1995), } \\
\text { Mölg et al. (2008). }\end{array}$ & $\pm 2 \% /< \pm 1 \%$ \\
\hline $\begin{array}{l}\text { bottom boundary con- } \\
\text { dition ice temperature }\end{array}$ & ${ }^{\circ} \mathrm{C}$ & $-1 \pm 1$ & $\begin{array}{l}\text { The ice was assumed to be near the } \\
\text { melting point on the basis of field mea- } \\
\text { surements and findings from Thompson } \\
\text { and Hastenrath (1981). }\end{array}$ & $\pm 8 \%$ \\
\hline
\end{tabular}

as measured or previously published (Table 3). A simple, single-parameter sensitivity analysis was performed on all of the model input parameters, in which individual model parameters were perturbed to the minimum and maximum of the parameter value ranges given in Table 3, while all other parameters were held constant at the central value of their respective ranges, and we report the impact of this parameter perturbation on modeled mass balance. The optimized parameter set was taken to be that resulting in the minimum root-mean-square difference (RMSD) between modeled and measured surface height and the model output using these optimized input parameters was used to calculate the SEB. Because modeled surface height increases are driven by the accumulation input derived from the measured surface height change, only the modeled surface lowering can be independently validated by the measured surface height change. Therefore, the modeled glacier surface temperature and the surface temperature computed from measured LWO are also compared as an independent measure of model performance. In addition, the modeled surface height change at the AWS is compared to that measured at a mass balance stake within $5 \mathrm{~m}$ of the AWS site to provide a second in- dependent evaluation. This stake was measured at 6-month intervals throughout the modeled period. Field observations indicate that there is no firn layer, so ice density was taken to be $900 \mathrm{~kg} \mathrm{~m}^{-3}$. Initial surface temperatures were computed from measured LWO at the start of each modeled period, and the initial internal temperature field was set to equal the initial surface temperature.

\section{Results}

\subsection{Meteorological conditions on Lewis Glacier}

A summary of the meteorological conditions measured at LG AWS is given in Table 4. The meteorological variables show strong diurnal cycles but weak and inconsistent seasonality (Fig. 2). $P$ variations are small and normally distributed, and on daily timescales are dominated by the semi-diurnal cycle (Dai and Wang, 1999). Periods of persistently high (February-June 2010) and low (December 2010February 2011) daily mean $P$ were recorded, and the variability in half-hourly $P$ readings is lower during the period May to September than in other months of the year. $T$ is nor- 


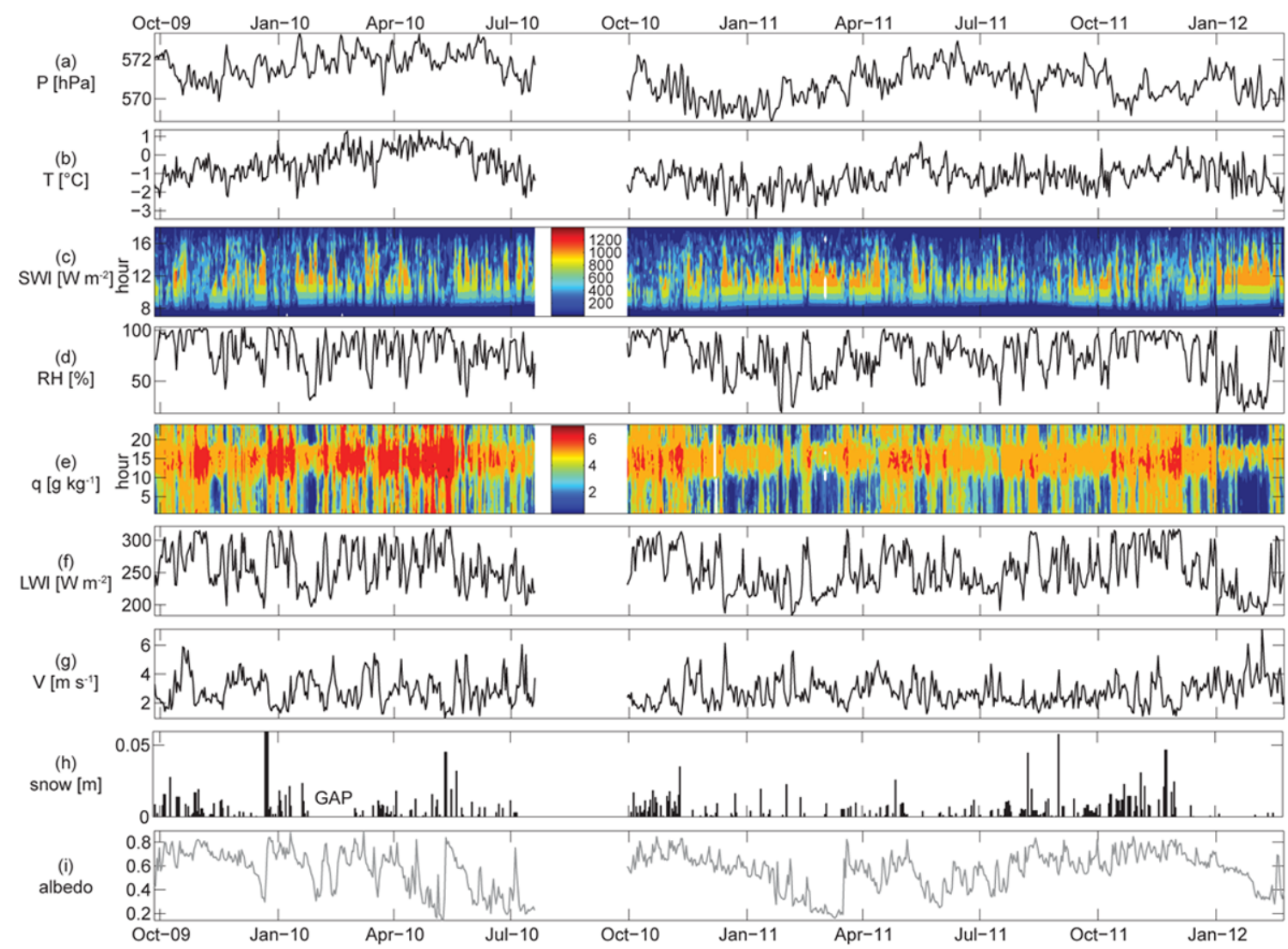

Fig. 2. Summary of daily mean meteorological conditions measured at Lewis Glacier AWS (4828 m Mt Kenya). Incoming shortwave radiation and specific humidity are shown as isopleth diagrams to highlight the evident afternoon development of cloud cover and peak specific humidity.

mally distributed with a mean value slightly below $0{ }^{\circ} \mathrm{C}$. The interquartile range of the 30 min means essentially remains below $0{ }^{\circ} \mathrm{C}$, but temperatures above freezing occur on an almost daily basis, with mean hourly $T>0{ }^{\circ} \mathrm{C}$ between 10:00 and 15:00, peaking at 11:00 (all time data in the text refer to local time). Daily mean $T$ broadly agrees with the periods of sustained high and low pressure, with a thermal optimum spanning February to June 2010 (Fig. 2a, b). During this optimum, some temperatures above $0^{\circ} \mathrm{C}$ were even recorded during nocturnal hours, while the lowest nocturnal air temperatures occurred in January 2011 and 2012.

Maximum hourly SWI exceeds the solar constant, which can be explained by multiple reflections of shortwave radiation between clouds and surface or between snow-covered surrounding and the measured surface, and the typical daily cycle shows suppression of SWI in the afternoon compared with the clear-sky parabola due to the frequent development of afternoon cloud cover. SWI is highest during January and February, and the only period of sustained clear skies occurred in January 2012 (Fig. 2c).

RH is typically $>50 \%$ (Fig. 2d) and is negatively skewed, with a strong peak near saturation values, emphasizing the typically moist state of the atmosphere at LG. The average diurnal cycle indicates $\mathrm{RH}<70 \%$ from 00:00 to 09:00, and peak RH and vapor pressure span 15:00-16:00 and 15:0017:00, respectively, 4-5 h after peak SWI. Near-saturation conditions at the AWS (defined as RH $>95 \%$ ) can occur at any time, and are reached in $>40 \%$ of the sampled days between the hours of 14:00 and 19:00, concomitantly with a daily peak in specific humidity (Fig. 2e).

Hourly LWI shows a bimodal frequency distribution, scatter plots (not shown) of LWI against both temperature and SWI/TOA during daylight hours indicate that these modes are associated with two dominant clusters of sky conditions representing clear and cloudy, and LWI shows temperature dependency only within these categories. Days for which nocturnal LWI values are high are associated with overcast sky conditions throughout all daylight hours. Examination of the frequency distribution of LWI by hour shows that the bimodal distribution is replaced by a single negatively skewed peak at $\sim 310 \mathrm{~W} \mathrm{~m}^{-2}$ between 13:00 and 17:00, emphasizing the frequent incidence of afternoon cloud formation. Furthermore, the monthly frequency distributions show that during MAM, August and OND the bimodal distribution is dominated by the peak at $\sim 310 \mathrm{~W} \mathrm{~m}^{-2}$, indicating a higher incidence of cloudiness during these months. 

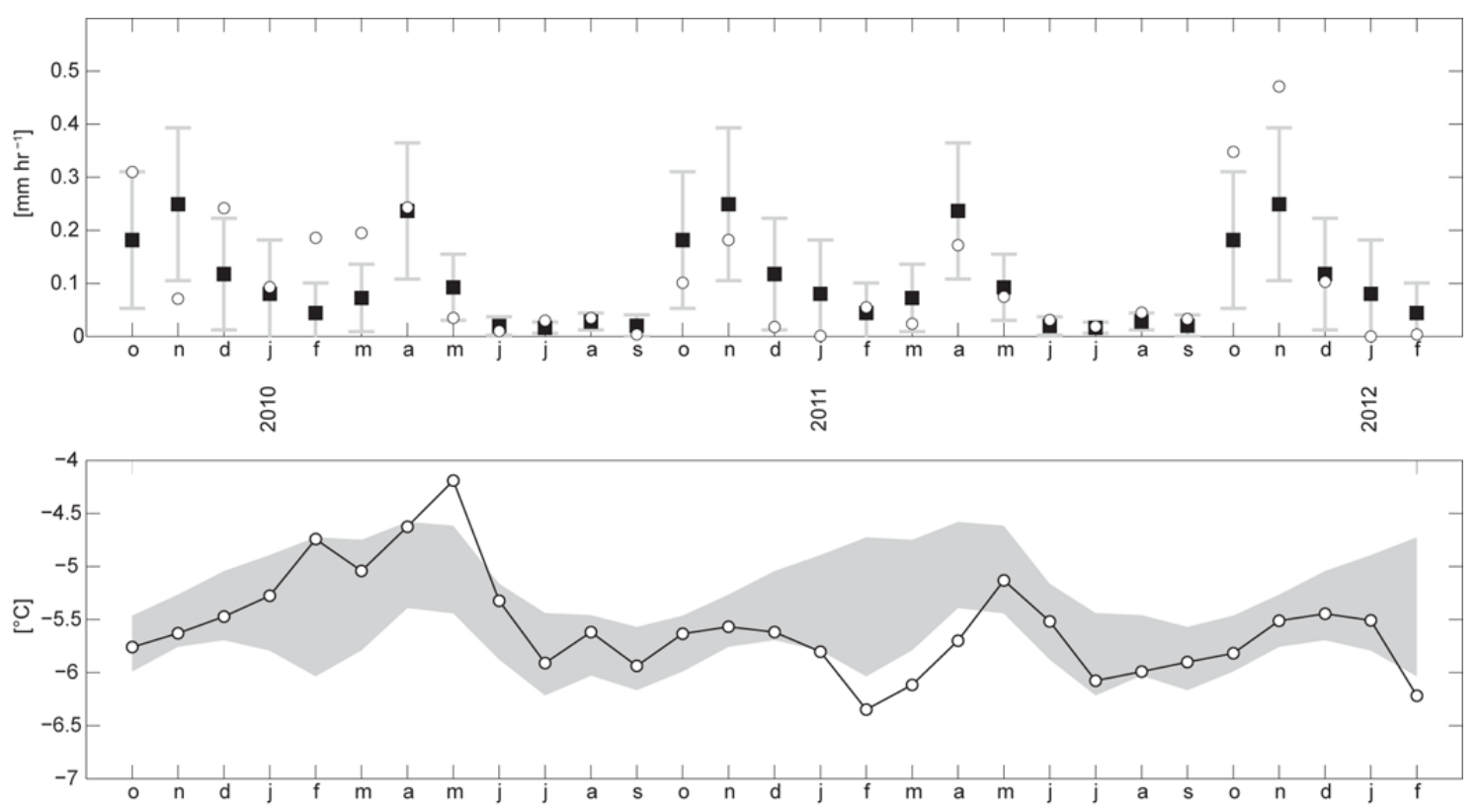

Fig. 3. Upper panel: Monthly TRMM precipitation rates for the study period (open circles) relative to the January 1998-July 2012 mean (black squares) and monthly standard deviations (gray error bars) for the grid point nearest Mt Kenya. Lower panel: Monthly ERA-Interim $500 \mathrm{hPa}$ air temperature averaged over 36.5 to $38.5^{\circ} \mathrm{E}$ and -1 to $1^{\circ} \mathrm{N}$ for the measurement period (open circles) relative to the range of the monthly mean temperature for January 1979-July $2012 \pm 1$ monthly standard deviation (gray shading).

Thus, the primary cause of bimodality of LWI is the diurnal cycle of cloudiness, and the secondary cause is a seasonal variation between cloudy and clear-sky conditions, although the seasonal pattern of LWI is not clearly evident in the daily time series (Fig. 2f). The distribution of hourly LWO shows a strong peak at $316 \mathrm{~W} \mathrm{~m}^{-2}$ due to the high frequency with which the glacier surface reaches the melting point during the daytime. July is the month with the lowest incidence of the glacier surface reaching the melting point. Assuming ice emissivity to be unity, LWO values translate into a mean glacier surface temperature of $-2.9^{\circ} \mathrm{C}$ (minimum $-16.6^{\circ} \mathrm{C}$ ).

$V$ is generally low and, on average, wind speed is $\sim 1 \mathrm{~m} \mathrm{~s}^{-1}$ faster during the night than during daylight hours, and declines sharply after sunrise to a late afternoon minimum. Maximum $V$ coincides with the prevailing wind direction that is from the northeast, partly conditioned by easterly atmospheric background flow and partly by channeling of this flow between the main and secondary summits of Mt Kenya. Although the daily mean wind speed does not reveal any seasonal variability, the monthly frequency distribution of $V$ shows fewer occurrences of high wind speeds in JAS, during which time the wind direction shows less frequent deviation from the prevailing northeasterly airflow than in other months.

Visual inspection of daily snow depth accumulation rate averaged over weekly and monthly intervals shows that only May of the 2010 long rains brought the accumulation rate above the all-month mean rate at the AWS, and that accumu- lation during the long rains in 2011 remained below the allmonth mean rate. In contrast, of the three short rains periods sampled, at least 2 months of each brought snow accumulation above the all-month mean. Additionally, accumulation was above the all-month mean during the dry season months of January 2010 and August and September 2011, when the accumulated snow depth equaled that of ON 2010. These data highlight the high degree of interannual variability in the duration and intensity of both the rainy and dry seasons in the summit region. Surface albedo is highly variable in the first part of the record, and, in the second half of the record, highest albedo coincides with the wet seasons (Fig. 2i).

\subsection{Representativeness of the measured period}

TRMM precipitation rate at the grid point nearest Mt Kenya is 1.5 times greater than that averaged over the region covering Mt Kenya and Kilimanjaro, most likely due to the enhanced precipitation associated with the mountain, but both spatial scales show the same pattern of seasonal and interannual variability. Accumulating precipitation gauges at the elevation of Lewis Glacier indicate mean annual precipitation of ca. $870 \mathrm{~mm}$ (standard deviation of $270 \mathrm{~mm}$ ) from 1979 to 1995 (Hastenrath, 2005), which compares well with the mean annual value of $855 \mathrm{~mm}$ for 14 full years of TRMM data (1998-2011) at the closest grid cell to Mt Kenya. The anomalies of total annual precipitation in 2010 and 2011 were -4 and $+17 \%$, respectively, of the annual standard deviation of TRMM precipitation $(269 \mathrm{~mm})$. For 
Table 4. Summary of 30 min meteorological data measured at LG AWS, computed for all 773 available days between 26 September 2009 and 22 February 2012 (missing data between 25 January and 2 March 2010, and between 20 July and 29 September 2010). Every second row refers to a single annual cycle, 1 October 2010 to 30 September 2011 . These data were used to compute the daily values shown in Fig. 2 and Table 2. Abbreviations are given in the text in Sect. 2.1 and values in parentheses for the SWI parameter were computed on daytime values only.

\begin{tabular}{|c|c|c|c|c|c|c|c|c|c|c|}
\hline & $\begin{array}{r}T \\
\left({ }^{\circ} \mathrm{C}\right)\end{array}$ & $\begin{array}{l}\mathrm{RH} \\
(\%)\end{array}$ & $\begin{array}{r}\mathrm{e} \\
(\mathrm{hPa})\end{array}$ & $\begin{array}{r}q \\
\left(\mathrm{gkg}^{-1}\right)\end{array}$ & $\begin{array}{r}\text { SWI } \\
\left(\mathrm{W} \mathrm{m}^{-2}\right)\end{array}$ & $\alpha$ & $\begin{array}{r}\text { LWI } \\
\left(\mathrm{W} \mathrm{m}^{-2}\right)\end{array}$ & $\begin{array}{r}\mathrm{LWO} \\
\left(\mathrm{W} \mathrm{m}^{-2}\right)\end{array}$ & $\begin{array}{r}V \\
\left(\mathrm{~ms}^{-1}\right)\end{array}$ & $\begin{array}{r}P \\
(\mathrm{hPa})\end{array}$ \\
\hline \multirow[t]{2}{*}{ mean } & -0.92 & 75.6 & 4.33 & 4.69 & $191(376)$ & 0.56 & 255 & 303 & 2.8 & 571.10 \\
\hline & -1.32 & 74.3 & 4.05 & 4.43 & $189(372)$ & 0.55 & 250 & 300 & 2.6 & 570.79 \\
\hline \multirow[t]{2}{*}{$\max$} & 6.61 & 100.0 & 7.64 & 8.35 & 1429 & 0.89 & 357 & 329 & 11.9 & 574.56 \\
\hline & 4.98 & 105.8 & 6.80 & 7.44 & 1326 & 0.85 & 345 & 328 & 11.9 & 573.89 \\
\hline \multirow[t]{2}{*}{$\min$} & -7.00 & 6.0 & 0.35 & 0.37 & 0 & 0.14 & 165 & 246 & 0.0 & 567.78 \\
\hline & -7.00 & 6.0 & 0.5 & 0.8 & 0 & 0.16 & 165 & 246 & 0.0 & 567.78 \\
\hline \multirow[t]{2}{*}{$25 \%$} & -1.85 & 59.6 & 3.30 & 3.54 & $0(105)$ & 0.46 & 206 & 290 & 1.7 & 570.35 \\
\hline & -2.19 & 56.3 & 2.95 & 3.22 & $0(100)$ & 0.46 & 202 & 287 & 1.6 & 570.09 \\
\hline \multirow[t]{2}{*}{$75 \%$} & 0.01 & 98.8 & 5.62 & 6.10 & $263(579)$ & 0.69 & 307 & 317 & 3.6 & 571.87 \\
\hline & -0.46 & 97.6 & 5.3 & 5.85 & $290(585)$ & 0.65 & 304 & 316 & 3.3 & 571.53 \\
\hline \multirow[t]{2}{*}{ median } & -0.94 & 86.2 & 4.86 & 5.23 & 0 (291) & 0.60 & 255 & 307 & 2.5 & 571.13 \\
\hline & -1.32 & 83.6 & 4.49 & 4.90 & $3(284)$ & 0.58 & 245 & 303 & 2.3 & 570.83 \\
\hline \multirow[t]{2}{*}{ st. dev } & 1.40 & 26.9 & 1.64 & 1.79 & $290(322)$ & 0.17 & 51 & 16 & 1.5 & 1.10 \\
\hline & 1.31 & 27.4 & 1.58 & 1.72 & $295(322)$ & 0.16 & 50 & 17 & 1.4 & 1.04 \\
\hline
\end{tabular}

the 29 months of the measurement period, seven months (December 2009; February, March, and July 2010; and August, October, and November 2011) experienced positive precipitation anomalies in excess of the standard deviation of the TRMM monthly mean precipitation rate and one month (November 2009) showed a negative anomaly (Fig. 3). Negative anomalies in monthly mean precipitation within one monthly standard deviation dominate the measurement period from May 2010 to May 2011, and again from December 2011 until the end of the record.

The ERA-Interim temperature data indicates that for the period of available measurements at Lewis Glacier, air temperature tended to be higher than the monthly average through February-June 2010, but only in May 2010 did the high temperature anomaly exceed the monthly standard deviation. Air temperature was anomalously low through January-April 2011 and in February 2012, and was generally lower than the monthly average from late 2010 until the end of the measurement period. The mean annual temperature cycle at $500 \mathrm{hPa}$ level in the ERA-Interim data shows that over the period 1979-2012, April and May experience the highest air temperatures, and July-October the lowest. Air temperature in February shows the greatest variability in this dataset.

\subsection{Mass and surface energy balance at Lewis Glacier}

The model reproduces measured surface temperature and measured surface height at both the AWS and at the mass balance stake very well (Fig. 4). RMSD between daily measured glacier surface height (SFC) and that modeled using the optimized parameter set is always $<11 \%$ of the amplitude of the surface change measured over the period, and deviations in daily surface change are normally distributed around 0 with $>90 \%$ within $\pm 4 \mathrm{~cm}$ of the measured SFC change. The correlation between measured and modeled hourly surface temperature is 0.77 . The sensitivity analysis indicates that the impact of single-parameter perturbation on modeled mass balance over the expected range of the parameter value is small for all the roughness terms, initial bulk snow density and the formation of superimposed ice. Percentage changes in modeled mass balance show most sensitivity to the penetration depth of daily temperature cycles, fresh snow density and the ice temperature at the bottom boundary of the model space. Therefore is it pertinent to briefly discuss the likely accuracy of these prescribed parameter value ranges, as these exert a control on the possible model solutions. Firstly, the glacier was assumed to be temperate based on (i) historical field measurements (Thompson and Hastenrath, 1981) and (ii) the absence of any high altitude accumulation area that could import colder ice to the glacier. As no subsequent field observations have contradicted these findings, the narrow parameter range used in the modeling appears to be well justified. The penetration depth range was determined by application of a heat diffusion model driven by surface temperatures derived from measured LWO, and the large mass balance response across the range is partially a result of allowing this penetration depth to vary over a relatively wide range $( \pm 20 \%)$ in order to reflect the potential influence of non-diffusive processes in the surface layer of the glacier. Modeled mass balance is sensitive to fresh snow density as this affects both the mass accumulation, which is input to the model as function of the measured surface height change multiplied by the fresh 

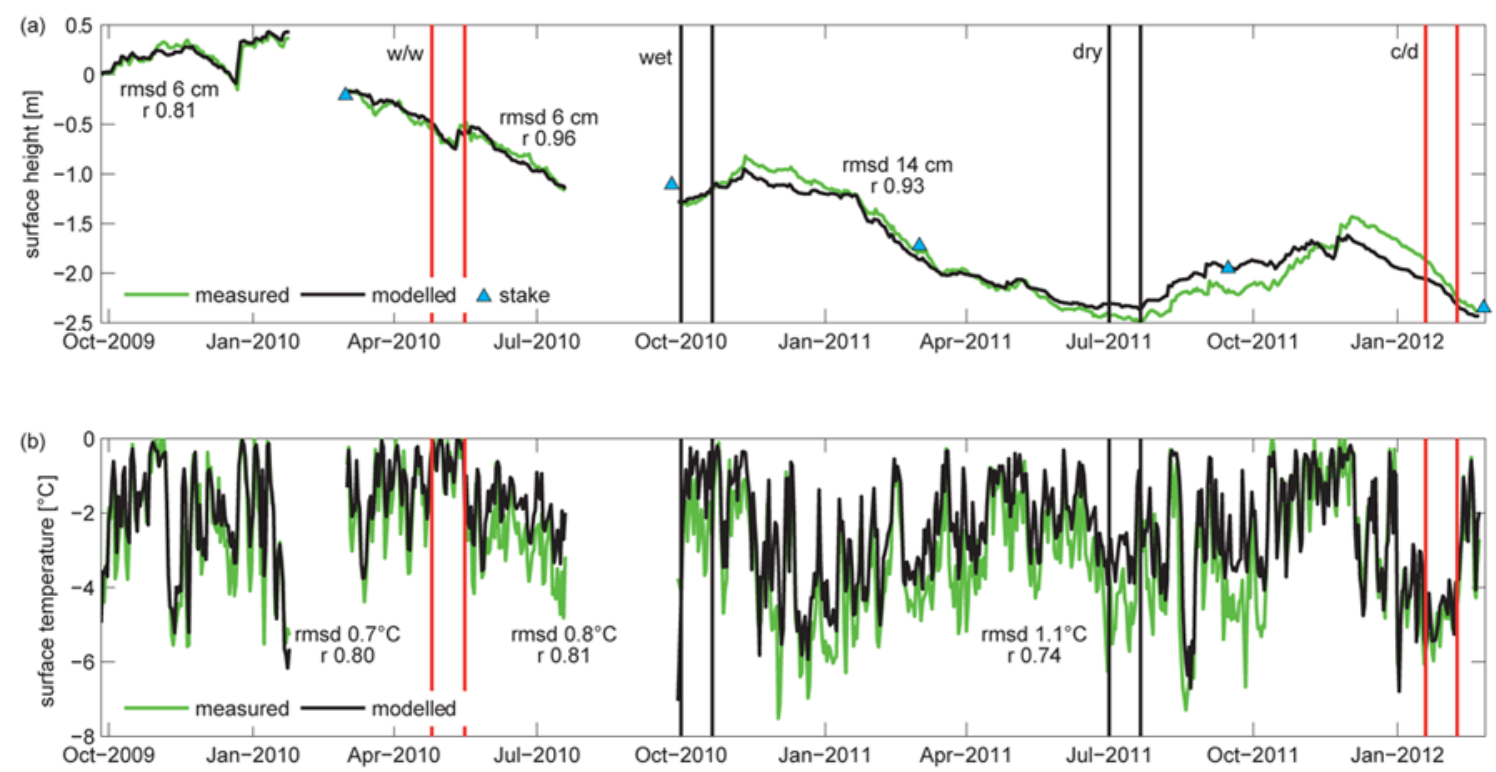

Fig. 4. (a) Comparison of measured and modeled surface height showing daily model performance metrics for each of the three periods, and comparison against a nearby mass balance stake. Vertical lines indicate the subsampled periods chosen to represent "typical" wet and dry conditions and warm/wet (w/w) and clear/dry (c/d) extremes. (b) Comparison of measured and modeled daily mean surface temperature.

snow density, and the surface energy balance by altering the portion of the model run time for which the surface is snow covered. Published fresh snow density values from the KG and ZG sites have been determined by direct (Mölg et al., 2008, 2009) and indirect observations (Sicart et al., 2002), as well as estimates derived from combining atmospheric model output with observations (Mölg and Scherer, 2012). These studies indicate that fresh snow density at low-latitudes is $>200 \mathrm{~kg} \mathrm{~m}^{-3}$, and at $\mathrm{KG}$ and ZG, which are both higher and colder than LG, measurements or calculations of maximum fresh snow density are $\geq 300 \mathrm{~kg} \mathrm{~m}^{-3}$. Thus the density range used for LG spans and exceeds the upper end of the published ranges of fresh snow density at KG and ZG, but as LG is both at a lower elevation and typically has a higher air temperature than these sites (Table 2), it is not unreasonable to have higher density snowfall at LG as indicated by the field measurements.

As was typical for the historical mass balance records (Hastenrath, 2005), LG experienced a negative mass balance over the measurement period (Prinz et al., 2012), and at the AWS, total surface lowering was $2.43 \mathrm{~m}$ (Fig. 4). The modeled mass balance summed over the three periods was $-1.59 \mathrm{~m}$ w.e., which equates to a mean balance rate of $-2.05 \mathrm{~kg} \mathrm{~m}^{-2} \mathrm{day}^{-1}$.

Monthly mean surface energy balance, mass flux components and meteorological conditions are shown in Fig. 5. In order to assess how surface energy balance differs between the seasons, it would be desirable to be able to identify typical wet and dry season conditions. However, this is challenging given the short and highly variable meteorological records. On the basis of the temperature, cloud and humidity conditions (Fig. 2) and on the representativeness of the measured period in comparison to the mean monthly conditions, subsamples from 1 to 20 October 2010 and 1 to 20 July 2011 were selected to represent "wet" and "dry" conditions, respectively. In addition, 26 April-15 May 2010 (20 days) and 19 January-7 February 2010 (20 days) were selected to represent extremes of warm/wet and clear/dry conditions and were chosen on the basis of coinciding with thermal optimum and humidity minimum in the measurements period, respectively.

Energy and mass fluxes averaged over the whole modeled period and over these subsamples (highlighted in Fig. 4) are presented in Fig. 6. The mean mass balance rate is markedly different between the periods: the wet conditions subsample sustains a balance rate of $2.99 \mathrm{~kg} \mathrm{~m}^{2} \mathrm{day}^{-1}$, compared to $-1.28 \mathrm{~kg} \mathrm{~m}^{2}$ day $^{-1}$ during the dry conditions subsample, while mean balance rates during the extreme warm/wet and clear/dry conditions were larger at $-9.25 \mathrm{~kg} \mathrm{~m}^{2} \mathrm{day}^{-1}$ and $-4.94 \mathrm{~kg} \mathrm{~m}^{2} \mathrm{day}^{-1}$, respectively, with the highest mass turnover occurring during the warm/wet extreme.

Turbulence-driven sublimation will be zero only if vapor pressure in the glacier boundary layer equals or exceeds that of the glacier surface, or wind speed is zero, whereas surface melt is conditional on glacier surface temperature reaching the triple point of water and additional energy being supplied to fuel melt. Consequently, sublimation occurred in $71 \%$ of the modeled hourly time steps, while surface melt occurred in only $14 \%$. Over the modeled period, mean energy consumed by sublimation $\left(21.6 \mathrm{~W} \mathrm{~m}^{-2}\right)$ exceeded that consumed by surface melt $\left(15.0 \mathrm{~W} \mathrm{~m}^{-2}\right)$, and sublimation accounts for $59 \%$ of the total energy consumed by ablation 


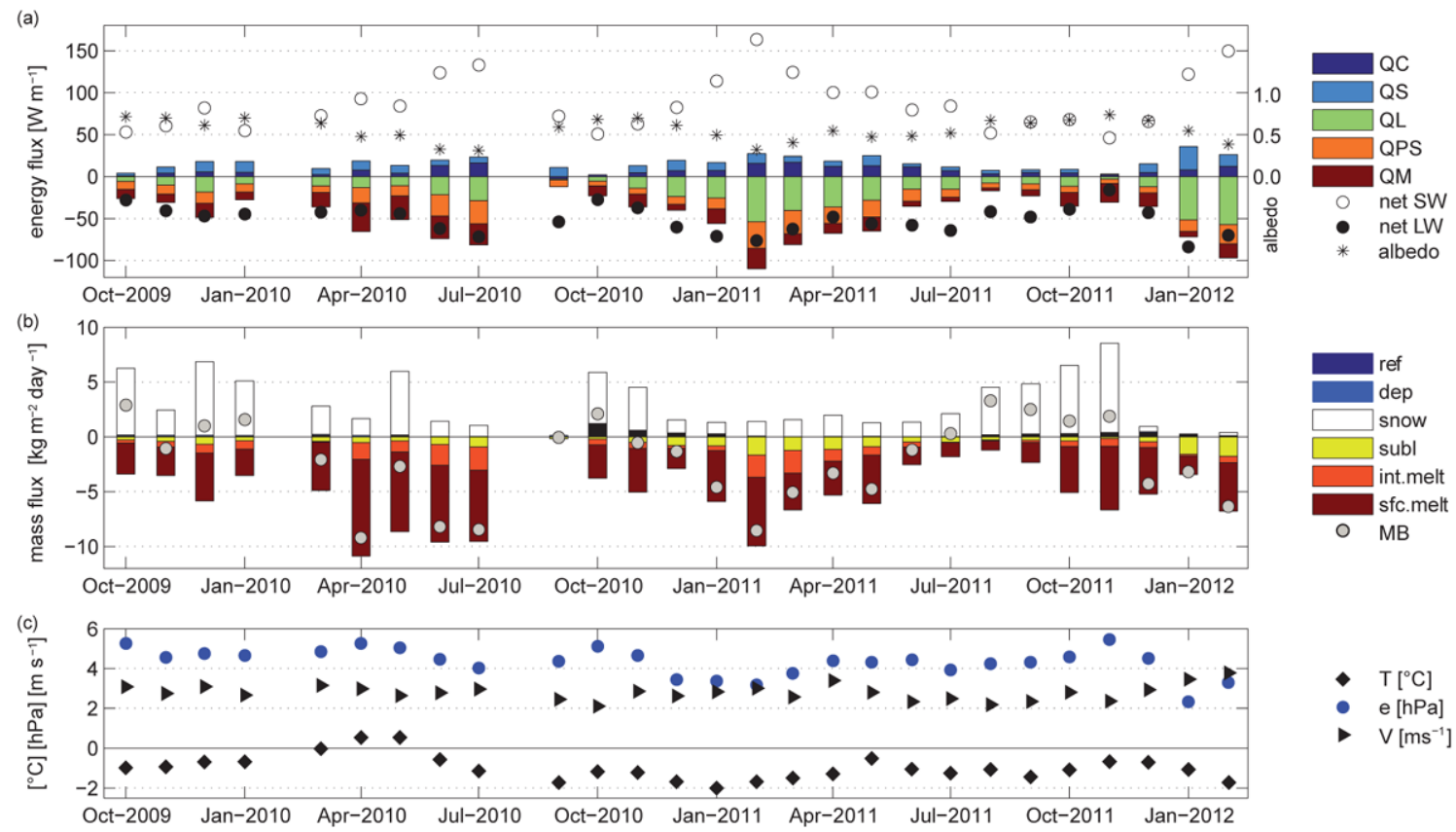

Fig. 5. (a) Monthly mean energy flux density of net shortwave radiation (net SW), net longwave radiation (net LW), conductive energy flux (QC), turbulent sensible energy (QS), turbulent latent energy (QL), penetrating shortwave radiation (QPS), energy for melting (QM) and surface albedo at Lewis Glacier AWS $(4828 \mathrm{~m}$ ). (b) Monthly mean mass flux rate of refreezing (ref), surface deposition (dep), solid precipitation (snow), sublimation (subl) internal melt (int.melt), surface melt (sfc.melt) and net mass balance rates (MB). (c) Monthly means of air temperature $\left(T\left[{ }^{\circ} \mathrm{C}\right]\right)$, vapor pressure $(\mathbf{e}[\mathrm{hPa}])$ and wind speed $\left(V\left[\mathrm{~m} \mathrm{~s}^{-1}\right]\right)$.

over the modeled period, but the higher energy efficiency of melt compared to sublimation means that mean surface melt rate $\left(3.89 \mathrm{~kg} \mathrm{~m}^{-2} \mathrm{day}^{-1}\right)$ was much higher than mean sublimation rate $\left(0.66 \mathrm{~kg} \mathrm{~m}^{-2}\right.$ day $\left.^{-1}\right)$, with maximum hourly modeled surface melt, and sublimation rates of $7.73 \mathrm{~kg} \mathrm{~m}^{-2}$ and $0.49 \mathrm{~kg} \mathrm{~m}^{-2}$, respectively. Generally sublimation rates were low and peak during the short periods of dry conditions during the periods of January-February 2011 and 2012 (Fig. 5). Thus, ablation at LG is dominated by melt, with the modeled glacier surface temperature reaching $0^{\circ} \mathrm{C}$ on 588 of the 773 modeled days. As ice temperatures throughout the depth of the modeled column are generally near the freezing point, $<4 \%$ of the combined surface and subsurface melt water produced is refrozen. Deposition rates are very low, and contribute only $2 \%$ of the total surface mass accumulation. Positive monthly mean mass balance rates generally occur when mean monthly solid precipitation rates exceed $4 \mathrm{~kg} \mathrm{~m}^{-2}$ day $^{-1}$.

Although the warm, moist and often cloudy atmosphere at LG means that LWI exceeds SWI in $75 \%$ of the hourly timesteps and that net longwave radiation is positive in $15 \%$ of the hourly cases, shortwave radiation is the largest net energy source to the glacier surface (Fig. 5a). Variations in net shortwave radiation flux at the surface are mirrored by net longwave losses, but averaged over the whole period, only $\sim 60 \%$ of the net shortwave radiation flux at the surface is offset by net longwave energy losses, resulting in a positive mean net radiative energy flux of $36.1 \mathrm{~W} \mathrm{~m}^{-2}$. Net radiation is reduced during cloud cover compared to clearsky conditions. The additional mean surface energy contribution from sensible heat flux is $8.4 \mathrm{~W} \mathrm{~m}^{-2}$, and mean monthly sensible heat flux is almost always positive (Fig. 5a). Mean conductive heat flux in the glacier surface layer is only directed into the glacier during the afternoon, but, combined with the penetrating shortwave radiation, mean energy flux within the glacier body is directed into the glacier throughout all daylight hours. The slightly negative ground heat flux at the surface (QC+QPS) indicates that the heat storage is increasing slightly during the modeled period. Mean latent heat flux is less negative throughout the daytime and is most negative at the beginning of the night. Melt occurred only during the daytime, with mean melt energy peaking from 14:00 to 15:00 and correlating most strongly with air temperature and net shortwave radiation. Positive monthly mean mass balance is only recorded when accumulation is near $5 \mathrm{~kg} \mathrm{~m}^{-2}$ day $^{-1}$, but this rate of accumulation does not guarantee positive mass balance (Fig. 5b).

Mean energy loss via net longwave flux during wet conditions $\left(-25.8 \mathrm{~W} \mathrm{~m}^{-2}\right)$ is less than half that of dry conditions $\left(-73.5 \mathrm{~W} \mathrm{~m}^{-2}\right)$, and mean net shortwave during the wet conditions $\left(49.3 \mathrm{~W} \mathrm{~m}^{-2}\right)$ is half that of the dry conditions $\left(100.8 \mathrm{~W} \mathrm{~m}^{-2}\right)$. Thus, the contrasts in the components of the radiative flux show the greatest contrast between the wet and dry conditions, although the resultant 
(i)

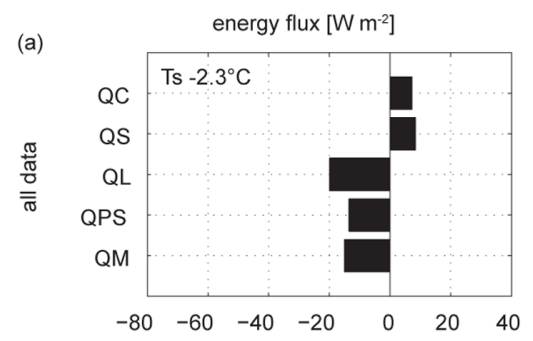

(b)
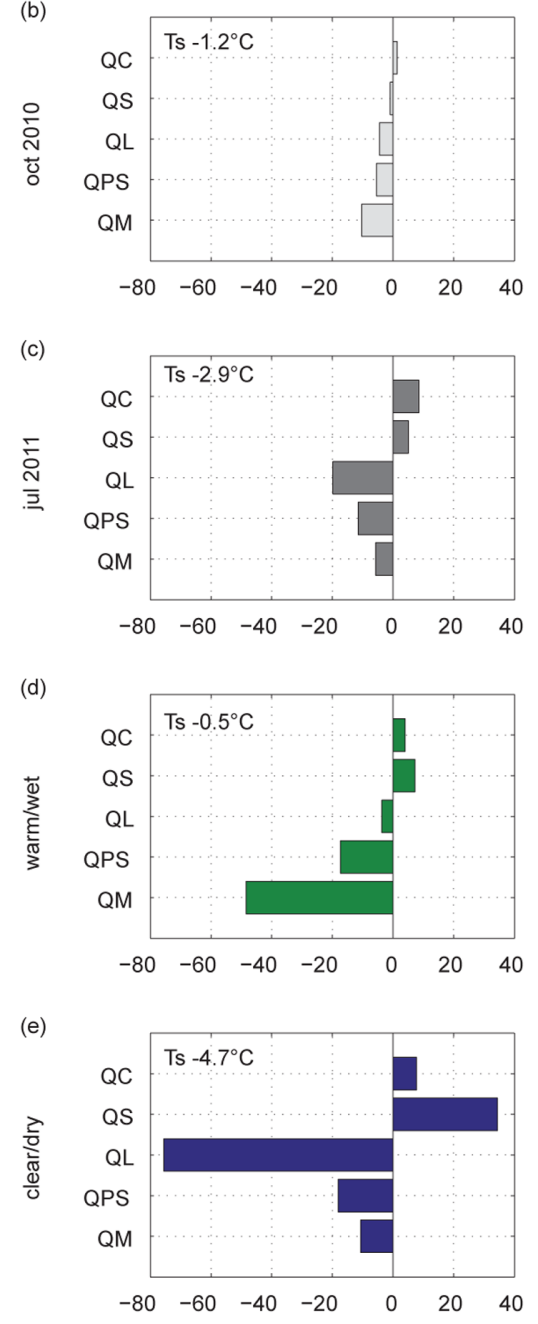

(ii)
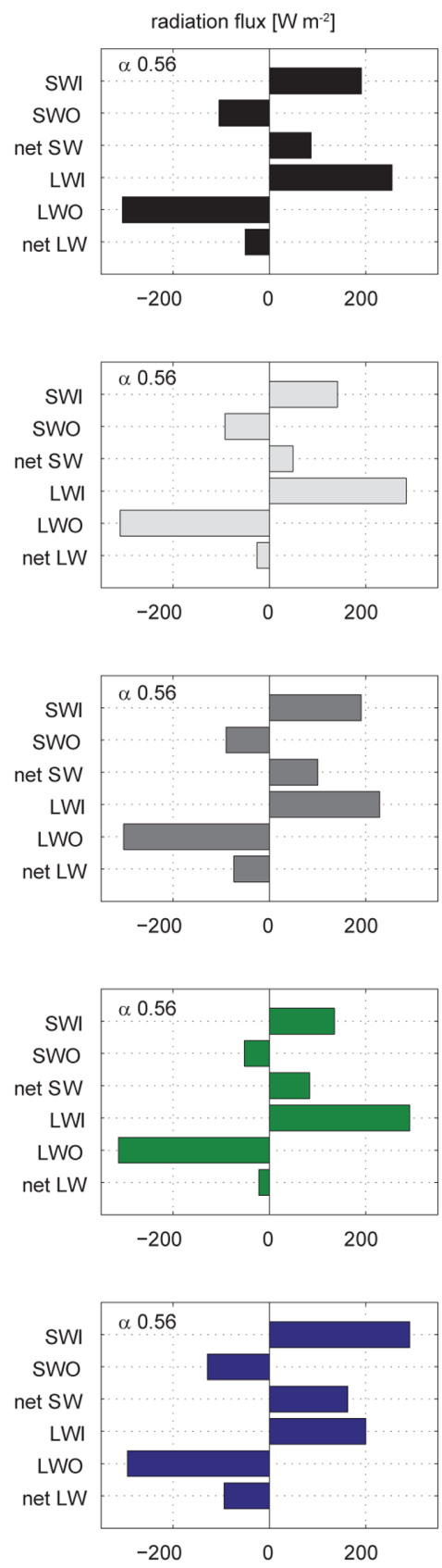

(iii)
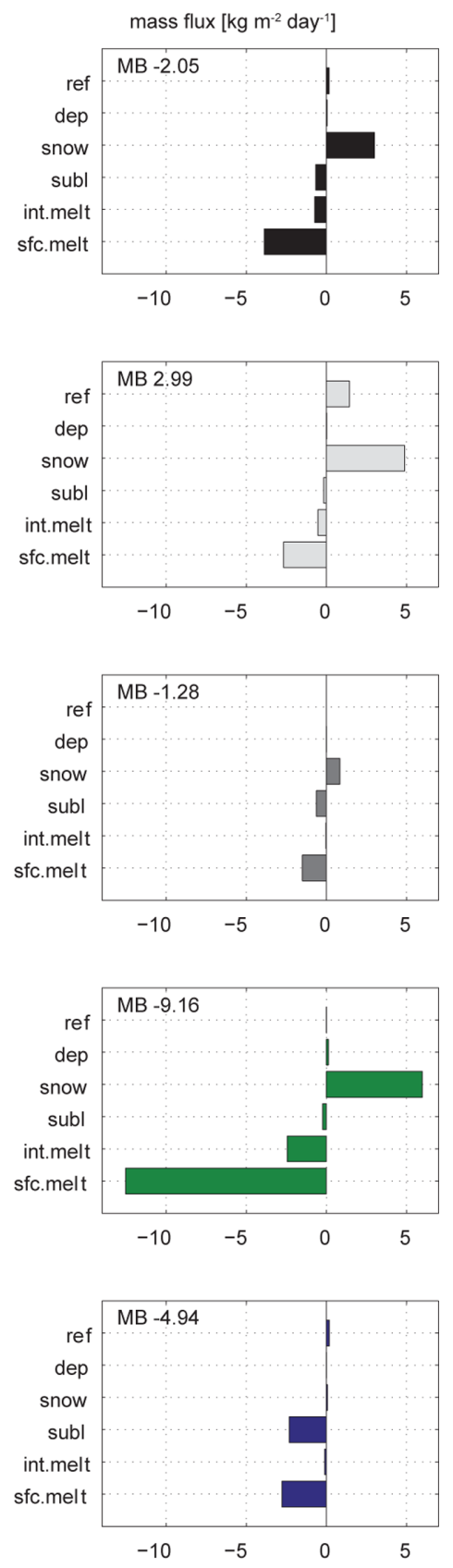

Fig. 6. Summary of (columns) (i) mean energy flux density, (ii) radiation flux components and (iii) mass fluxes at the AWS site on LG in (rows) (a) the whole modeled period, (b) standard wet conditions (1-20 October 2010), (c) standard dry conditions (1-20 July 2011), (d) 20 days of warm/wet extreme (26/04/2010-15/05/2010) and (e) 20 days of clear/dry extreme (19/01/2012-7/02/2012).

mean net radiative fluxes are similar at 23.4 and $27.3 \mathrm{~W} \mathrm{~m}^{-2}$, respectively (Fig. 6b and c). During wet conditions, the nonradiative energy flux exchanges are reduced compared to dry conditions, as the surface-to-air gradients in temperature and humidity are smaller. Mean surface temperature during the wet $\left(-1.2^{\circ} \mathrm{C}\right)$ and dry $\left(-2.9^{\circ} \mathrm{C}\right)$ conditions give a mean temperature difference between air and surface conditions of $0.1^{\circ} \mathrm{C}$ and $1.4^{\circ} \mathrm{C}$, respectively. Consequently, mean sensible heat flux during wet conditions is $<1 \mathrm{~W} \mathrm{~m}^{-2}$.

The mean difference in saturation vapor pressure at the glacier surface temperature and the atmospheric vapor pressure in wet conditions was $0.34 \mathrm{hPa}$ compared to $1.28 \mathrm{hPa}$ in dry conditions, while wind speed is only slightly lower in the wet conditions than it is in dry conditions. Consequently, 
differences in the sublimation rate between wet and dry conditions are primarily driven by the contrasting vapor pressure gradient, rather than by wind speed (Fig. $6 \mathrm{~b}$ and c). In the subsample of wet conditions $34 \%$ of energy available for surface ablation is consumed to sublimate $3.23 \mathrm{~kg} \mathrm{~m}^{-2}$ of ice rising to $77 \%$ to sublimate a total of $12.42 \mathrm{~kg} \mathrm{~m}^{-2}$ of ice during the subsample of dry conditions. During the wet conditions, mass turnover is higher than in the dry conditions and combined surface and internal melting was more than double that of the dry conditions. While mean air temperature during the wet and dry conditions differs by only $0.2^{\circ} \mathrm{C}$, the difference in mean latent heat flux between subsamples wet and dry of conditions at $\mathrm{LG}$ is $15 \mathrm{~W} \mathrm{~m}^{-2}$ compared to differences in mean net shortwave and longwave fluxes of 51 and $-48 \mathrm{~W} \mathrm{~m}^{-2}$.

During the wet and warm/wet extreme conditions at LG, LWI is only slightly elevated in comparison to the mean LWI over the whole period; however, enhancement in LWI from the clear/dry extreme to the wet and warm/wet conditions is $42 \%$ and $46 \%$, respectively, which is between the upper limit of cloud cover LWI enhancement for midlatitudes and the humid season enhancement typical for outer tropical glaciers (Sicart et al., 2005). The sum of the turbulent fluxes during the extreme warm/wet conditions is positive because sublimation is dramatically reduced and accounts for consumption of only $14 \%$ of the energy available for ablation in these conditions, while air temperature $>0{ }^{\circ} \mathrm{C}$ means that the sensible heat flux is positive instead of negative, as it is during the subsample of wet conditions from October 2010.

During the warm/wet extreme, high accumulation and surface melt rates result in the highest mass turnover of all the analyzed periods, with snow accumulation rates of $6.0 \mathrm{~kg} \mathrm{~m}^{-2}$ day $^{-1}$ more than offset by surface ablation of $-12.7 \mathrm{~kg} \mathrm{~m}^{-2} \mathrm{day}^{-1}$ (Fig. 6d). Thus, although wet conditions can be a period of mass accumulation for the glacier, if they coincide with a period of protracted above-freezing air temperatures, vigorous ablation due to high melt rates can more than offset the accumulated snowfall. Despite similar surface albedo values, net radiation in the clear/dry extreme is 2.5 times that of the typical dry conditions, primarily because fairly frequent cloud cover in typical dry conditions reduces the SWI compared to that in the clear/dry extreme (Fig. 6c and e), and this drives strongly enhanced surface ablation compared to the more typical dry conditions. During the extreme clear/dry conditions, $88 \%$ of energy available for surface ablation is consumed by sublimation and sublimation rate is almost equal to the surface melt rate (Fig. 5e). The difference in mean latent heat, net shortwave and net longwave fluxes between the wet conditions and the clear/dry extreme subsample are 71,113 and $-69 \mathrm{~W} \mathrm{~m}^{-2}$, respectively. In both sets of extreme conditions, the mean mass balance rate was more negative than during the July subsample of dry conditions.

\section{Discussion}

\subsection{Comparison of mean conditions at LG with other glaciated tropical sites}

As is typical for low-latitude locations, none of the sites show pronounced seasonal variability in air temperature (Kaser and Osmaston, 2002; Mölg et al., 2009a; Lentini et al., 2011), and mean air temperatures over the respective measurement periods were close to $0^{\circ} \mathrm{C}$ at all sites except KG, with abovefreezing mean temperatures measured in the ablation zone of AG and ARG. At KG both atmospheric and glacier surface temperatures are lower, and more variable, than at the other sites, and KG also experiences a markedly drier atmosphere. EG is the most humid and cloudy site, with persistently overcast conditions during daylight hours in contrast to the afternoon development of cloud cover seen at LG and to a lesser extent at $\mathrm{AG}$, and the prevailing clear skies at KG.

At $K G$, vapor pressure, cloudiness and accumulation show clear peaks during active wet seasons (Mölg et al., 2009a), whereas at LG the active wet seasons show only very slight increases in vapor pressure and cloudiness on seasonal timescales, and can only be differentiated from mean conditions by increased precipitation amounts. At EG, these intraseasonal offsets are not evident at all, although direct comparison of published values is hampered by the definition of the rainy seasons at EG as MAMJ and SOND (Lentini et al., 2011). Average long and short rainy season precipitation rates, calculated from total seasonal precipitation measured with an accumulating rain gauge near Lewis Glacier between 1981 and 1990 (Hastenrath, 2005), were 3.4 and $3.3 \mathrm{~mm} \mathrm{day}^{-1}$, respectively, which are slightly lower than precipitation rates at EG over the four months of the long and the short rains of 4.1 and $4.6 \mathrm{~mm} \mathrm{day}^{-1}$, respectively (Lentini et al., 2011). This suggests that precipitation is not only more continuous at EG, but also more intense, with peak precipitation rate occurring in the SOND season. There is no evidence of failed rainy seasons in the available data from EG as high precipitation rates are sustained year round (Lentini et al., 2011). However, rainy seasons with no appreciable increase in accumulation compared to the dry season accumulation rate in MAM at LG and in OND at KG (Mölg et al., 2009a) may indicate differences in the precipitation seasonality between the two sites: at KG, the long rains appear to be more reliable and bring the most snow, while the short rains are more variable, and thus exert a strong control on interannual glacier mass balance (Mölg et al., 2009a); conversely, in the short record available here, the short rains at LG appear more reliable than the long rains. In the historical precipitation records from rain gauge measurements (19781996), MAM appears to be more variable than OND, with mean MAM precipitation of $314 \mathrm{~mm}$ (st. dev. $139 \mathrm{~mm}$ ) and mean OND precipitation of $302 \mathrm{~mm}$ (st. dev. $100 \mathrm{~mm}$ ). 
At KG, the period of JJAS experiences the fewest summit snowfall events, a feature that has been attributed to reduced incident solar radiation as a stronger East African low-level jet brings moisture and stratiform cloud to the region, instead of deep convection that brings precipitation to the summit (Pepin et al., 2010). During the shorter JF dry season on Kilimanjaro, the short rains often extend into January and snowfall at the summit of Kilimanjaro is comparable with that of the regional wet seasons (Chan et al., 2008). Higher JF accumulation here could also be a result of moisture supply from the northern edges of the tropical rainfall belt in its most southerly position, augmented by enhanced Atlantic moisture transport to East Africa in some austral summers (e.g., Whittow, 1960; McHugh, 2004). In contrast, at LG and EG, JF appears to be more consistently arid than the JJAS period, possibly because these sites lie northward of the influence of the low-level jet, and additionally because at this latitude some moisture can spill over from the Congo Basin during the JJAS dry season (McGregor and Nieuwolt, 1998). The aridity of the JF season at EG has been attributed to the influence of dry northerly airflow when the ITCZ is in its southernmost position (Whittow, 1960; Lentini et al., 2011), and this is also evident in back trajectory analysis for Mt Kenya (Henne et al., 2008). However, historical mean monthly precipitation measured in rain gauges near LG from 1981 to 1990 (Hastenrath, 1984) does not reveal the JF season to be markedly drier than the JJAS one, so this may be a recent and/or short-lived characteristic.

On climatological timescales, these relationships describe the impacts of the fairly loose boundaries of the tropical rainfall belt on the mountains that, although separated by only a few degrees in latitude, are sensitively located near the edge of the ITCZ at its most northerly and southerly positions the exact locations of which are influenced by multiple airflows, convergence zones and conditions in both the Atlantic and Indian oceans.

In the ablation zone of AG, meteorological conditions are similar to those of the upper glacier at LG and it is very difficult to identify seasonal variations (Favier et al., 2004a). In contrast to the equatorial East African glaciated sites that show no seasonal variation in wind speed, at AG wind speed shows the most pronounced variation throughout the year and has been used to identify two contrasting periods within the year: a windy, moderately cool, and dry period spanning JJAS, and the rest of the year when both mean wind speed is lower and the atmosphere is slightly warmer, moister, and more cloudy with resultantly slightly larger LWI (Favier et al., 2004b). Superimposed on this seasonality, cloudiness is somewhat enhanced during MAM and OND (Francou et al., 2004). Data from $4650 \mathrm{~m}$ spanning 1994-2003 show that precipitation occurs year-round with a multi-month, but variable, precipitation maximum between February and June and another single wetter month generally occurring between October and December (Favier et al., 2004b; Francou et al., 2004). This precipitation seasonality has been interpreted as an effect of the leakage of the Amazonian rainfall cycle into the seasonal cycle of the inter-Andean Valley (Vuille et al., 2008). In contrast to LG, where active wet seasons are associated with marked positive anomalies in monthly snow accumulation, it appears that over annual timescales the ablation zone of AG does not experience a pronounced seasonality in accumulation, although the occurrence of rainfall instead of snowfall is more frequent during the wetter and warmer period (Favier et al., 2004b). ARG, ZG (Favier et al., 2004a) and KG (Mölg et al., 2008) show clear seasonal offsets in net longwave radiation on the order of $50-60 \mathrm{~W} \mathrm{~m}^{-2}$. Seasonal offsets in net longwave radiation are more muted at $\mathrm{AG}$, where differences are on the order of $20 \mathrm{~W} \mathrm{~m}^{-2}$. At $\mathrm{LG}$ the magnitude of monthly mean net longwave radiation is generally most negative during the JF season and least negative during ON (Fig. 5a). The range in monthly mean net longwave is greater at $\mathrm{LG}$ than at $\mathrm{AG}$, and approaches that of the seasonal offsets at KG, ARG and ZG, although the maximum and minimum net longwave conditions at LG are expressed within single months rather than sustained seasons. At LG, the most evident perturbation of LWI occurs during brief intervals of sustained clear-sky conditions, which indicates that the typical cloud conditions serve to elevate atmospheric longwave emissions by between 14 and $45 \%$ compared to that of clear, dry atmospheric conditions, while at ZG the presence of clouds during the humid season increases LWI by $>50 \%$.

\subsection{Comparison of conditions at Lewis and Kersten glaciers 1 October 2009-19 July 2010}

LG and KG AWSs are separated by $320 \mathrm{~km}$ horizontally and $1054 \mathrm{~m}$ vertically. For the $<10$ months of the overlapping measurements, variations in daily mean conditions except for SWI are broadly synchronous at the two sites (Fig. 7), and variables are significantly correlated between the two sites. Correlation coefficients between ERA-Interim zonal and meridional wind components at the single grid points of Kilimanjaro and Mt Kenya at all levels between 650 and $300 \mathrm{hPa}$ are between 0.8 and 0.87 . Monthly mean wind fields near the ERA-Interim model surface and at the $550 \mathrm{hPa}$ level show that both near-surface and mid-tropospheric air flow are relatively homogenous across the two mountains. Air flow patterns at the summit locations only differ during JF, when mean surface easterly winds diverge slightly across the equator, and in June, when there are strong longitudinal gradients in mean upper air flow strength and direction. Back trajectories support this pattern on a daily basis, with the surface and upper level flows showing very similar trajectory distributions throughout both the long and the short rains. These lines of evidence both indicate that the weather stations on $\mathrm{KG}$ and LG are typically influenced by the same air masses.

Environmental lapse rates in air temperature, humidity, radiation, pressure and wind speed unsurprisingly play a decisive role in the contrasting conditions between KG and 

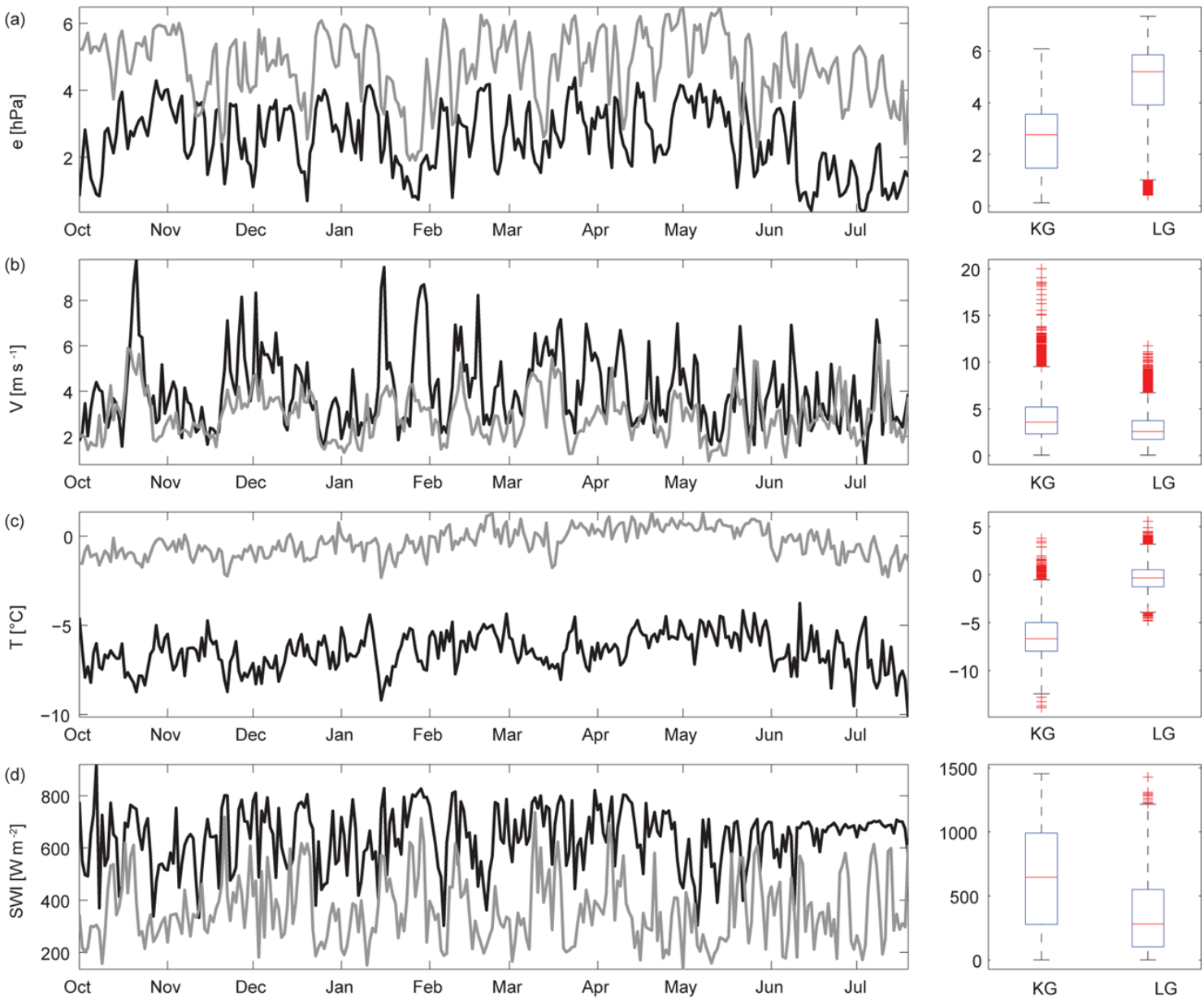

Fig. 7. Comparison of daily mean values of (a) vapor pressure, (b) wind speed, (c) air temperature and (d) incoming shortwave radiation averaged over daylight hours at KG (black line) and LG (gray line). Box plots to the right show the median, interquartile range and outliers of each meteorological variable measured at LG and LG AWS over the period of common measurement (1 October 2009-19 July 2010).

LG (Fig. 7). The temperature lapse rate between the two AWS locations during the overlapping measurements is $-5.8^{\circ} \mathrm{C} \mathrm{km}^{-1}$, compared to a mean annual temperature lapse rate of $-5.5^{\circ} \mathrm{C} \mathrm{km}^{-1}$ determined on Kilimanjaro (Pepin et al., 2010). Because of the elevation difference, even the minimum air temperature at $\mathrm{LG}$ exceeds the mean temperature at $\mathrm{KG}$ and the interquartile ranges of atmospheric vapor pressures at the two sites do not overlap, with LG typically experiencing vapor pressures spanning $3.9-5.9 \mathrm{hPa}$ compared to $1.5-3.6 \mathrm{hPa}$ at $\mathrm{KG}$, again emphasizing the low temperature and aridity of the conditions at KG compared to LG. During the overlapping measurement period, mean glacier surface temperatures at $\mathrm{LG}$ and $\mathrm{KG}$ AWS are -2.2 and $-7.8^{\circ} \mathrm{C}$, respectively. Saturated vapor pressure values with respect to water at these temperatures are 5.20 and $3.40 \mathrm{hPa}$, which, compared to the mean atmospheric vapor pressure at each sites, gives surface-to-air offsets of 0.45 and $0.84 \mathrm{hPa}$. The stronger gradient, coupled with higher wind speed at $\mathrm{KG}$, indicates that conditions there are more favorable for subli- mation. Radiation data from the AWSs on LG and KG also show a marked difference in the dominant sky conditions at the two sites. Clear-sky days occurred for 5 and $45 \%$ of the days of the overlapping measurement period at $\mathrm{LG}$ and $\mathrm{KG}$, respectively (Fig. 8). Overcast sky conditions occur only sporadically at KG but are an almost daily event at LG, where atmospheric saturation (indicative of conditions suitable for cloud formation at the elevation of the AWS) occurred in $25 \%$ of the hourly readings compared to $18 \%$ at KG. At both sites, the sonic rangers recorded surface accumulation during $20 \%$ of the days sampled, but only $40 \%$ of these accumulation days were simultaneous at both sites, despite the evidence for common air mass source areas.

Theoretical considerations (Schär, 2002), measurements (Pepin et al., 2010) and limited-area atmospheric modeling on Kilimanjaro (Mölg et al., 2009b; Mölg and Kaser, 2011) show that, due to their size, the isolated mountains of East Africa frequently experience a flow-around rather than flowover regime, such that convective lifting of air is equally or 


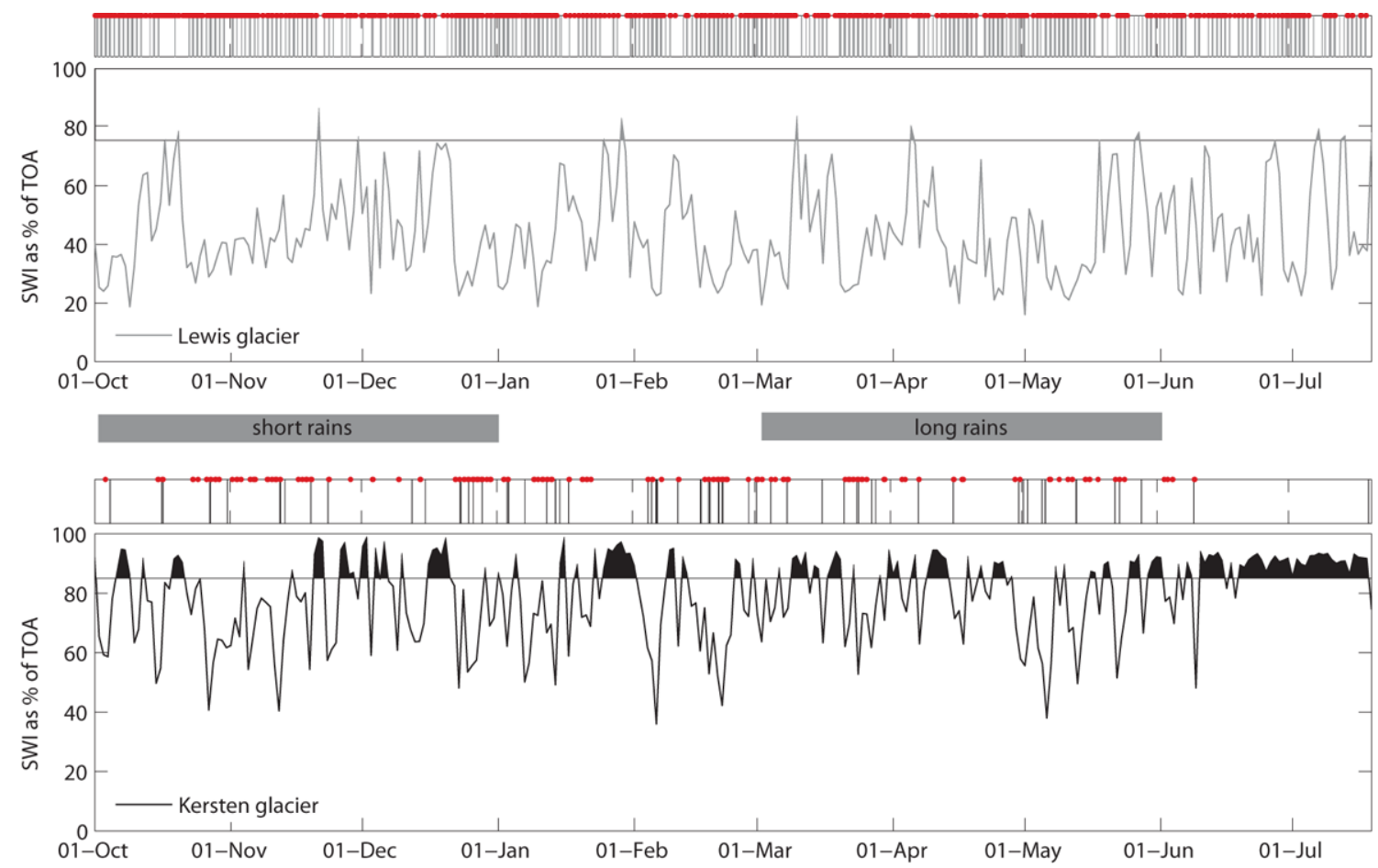

Fig. 8. Time series of daily incoming shortwave (SWI) as a percentage of extraterrestrial radiation (TOA) indicates clear-sky periods (above the horizontal line) when the ratio exceeds the respective limit for Lewis (75\%) and Kersten (85\%) glaciers. Panels above show a concurrent hourly time series of overcast sky conditions (vertical bars) and hours when atmospheric humidity reaches condensation conditions (red dots) at the AWS site. The gray bars in the center highlight the OND and MAM regional rainy seasons.

more important than topographic lifting in terms of summit cloud formation and precipitation. This is reinforced by (i) the afternoon development of cloud cover development at LG and (ii) the decisive linkage of snowfall events at the Kilimanjaro summit to low wind speed and high humidity conditions in the lower atmosphere that favor deep convection (Chan et al., 2008; cf. Mölg et al., 2009b; Mölg and Kaser, 2011). In the dry season, idealized modeling indicates that stable or near-neutral conditions in the $850-600 \mathrm{hPa}$ layer can prevent uplift of moist air above $\sim 5500 \mathrm{~m}$ (Mölg et al. 2009b), a height that is above the glaciers of Mt Kenya but below most of the ice on Kilimanjaro. This finding was reaffirmed recently by atmospheric modeling performed with a realistic setup, showing that intraseasonal variability in summit precipitation on Kilimanjaro can be explained by nearstable layer formation at $\sim 635 \mathrm{hPa}$ in the mornings (Mölg and Kaser, 2011). An earlier concept proposed that mountain geometry could also modify radiatively driven convective cloud formation on Kilimanjaro and Mt Kenya, such that the concave upper slopes of Mt Kenya allow for cloud convergence over the summit, while the convex upper slopes of Kilimanjaro inhibit clouds from closing over the summit (Kaser and Osmaston, 2002). The data over the PCM at LG and KG support differences in moisture transport to the mountain summits that result in more frequent convergence of convective clouds over the summit of Mt Kenya compared to the summit of Kilimanjaro.

The majority of positive daily surface height changes at $\mathrm{LG}$ are $<5 \mathrm{~cm}$, as was previously determined for the KG site (Mölg et al., 2009b). The snow depth accumulation rate over the PCM at LG (mean of $0.87 \mathrm{~cm} \mathrm{day}^{-1} ; 98$ events) was $35 \%$ greater than at $\mathrm{KG}$ (mean of $0.64 \mathrm{~cm} \mathrm{day}^{-1} ; 118$ events). Converting to water equivalent values using the 90th percentile of measured fresh snow densities from field measurements $\left(\mathrm{LG}=420 \mathrm{~kg} \mathrm{~m}^{-3} \mathrm{KG}=255 \mathrm{~kg} \mathrm{~m}^{-3}\right)$, there is more than twice as much mass accumulation at LG than at KG over the same period, with KG mass accumulation being 82 and $36 \%$ of that at LG in MAM and OND, respectively. These ratios are partly affected by the strength of the wet season at each site: at KG, the OND 2009 rainy season brought accumulation only slightly elevated above the all-month mean, and at LG, the MAM 2010 season was relatively poorly expressed, with accumulation concentrated in May. Furthermore, on the basis of the different snow densities measured at each site, the snow density is likely to show temperature-dependent variation, which is not accounted for in this analysis. 


\subsection{Comparison of Lewis Glacier SEB with other tropical glaciers}

As the point energy balances of the glaciers were computed over different periods, come from different locations on the glacier surface, and were computed using different models, they are not directly comparable. Therefore, this discussion focusses on the general factors controlling variability of energy and mass balance at the sites, and how these influence the interpretation of tropical glaciers as climate proxies.

At many glacier sites, LWI exceeds SWI on daily and longer timescales, and this has been proposed as an explanation for the success of degree day models in determining glacier ablation (Ohmura, 2001). However,LWI is poorly correlated to melt energy because melting occurs primarily in daylight hours, while a significant amount of the LWI is delivered during the night. Sicart et al. (2008) demonstrated that, at high latitudes, temperature is well correlated with melt energy via the turbulent energy fluxes; however, at mid and especially at low latitudes, SWI controls the variability of melt energy. Consequently, the temperature sensitivity of glacier surface energy balance in these latitudes is limited, which agrees well with previous studies across the range of latitudes (Braithwaite, 1981; Ohmura 2001; Mölg and Hardy, 2004). At all sites in this study, shortwave radiation is the most variable and largest net source of energy to the surface, with longwave radiation being the greatest net energy loss (Favier et al., 2004a; Mölg et al., 2008; Juen, 2006). The dominance of net surface shortwave radiation as a source of energy to the glacier surface means that at diurnal timescales all these glaciers are very sensitive to albedo and less sensitive to temperature than lower elevation mid- to high-latitude glaciers (Favier et al., 2004a, b; Mölg et al., 2006b, 2008, 2009a), and this can be expected to be particularly true for KG, where mean SWI exceeds LWI (Table 2; Mölg et al., 2008). At AG, melt rates throughout the annual cycle are inversely related to surface albedo, which is primarily governed by solid precipitation. Similarly, at LG, daily melt energy shows significant negative correlation with albedo and positive correlation with SWI, but also weaker significant correlations with temperature wind speed and vapor pressure. At both LG and AG, ablation is only effectively inhibited by solid precipitation through its combined effect on mass accumulation and the shortwave radiation balance.

Over annual timescales, air temperature at low latitudes is better correlated with mass balance, as it captures variations in both ablation processes and accumulation driven by phase of precipitation (Favier, et al., 2004b; Sicart et al., 2008). At glacier sites where liquid precipitation is possible (such as AG), glacier-wide mass balance variability is sensitive to temperature variations through its control on the phase of precipitation that dictates the proportion of the glacier surface that will experience solid or liquid precipitation (Favier et al., 2004b; Francou et al., 2004). At higher elevations (such as $\mathrm{KG}$ ), where all precipitation is solid, glacier mass bal- ance sensitivity is dominated by precipitation alone (Mölg and Hardy, 2004; Mölg et al., 2009a). At LG, both historical (Hastenrath, 1984) and recent observations suggest all the precipitation is solid, and even periods of high temperatures such as April/May 2010 still bring significant snow accumulation, suggesting that liquid precipitation is rare or absent, even during positive temperature anomalies. Field measurements of fresh snow fall events in September 2010 show that the depth of snow accumulated is almost constant across the surface area of this very small glacier. These observations suggest that neither the amount nor the phase of precipitation varies significantly over the surface of $L G$, and it thus appears unlikely that the glacier-wide mass balance will show sensitivity to temperature due to partitioning between solid and liquid precipitation as at AG. It is, however, evident that during warm temperature anomalies, accumulated snow mass at LG is rapidly removed by vigorous surface melt.

Melting can only occur if the other components of the energy balance are such that additional energy remains for the passive process of melting. Because sublimation consumes 8 times more energy than melting, high sublimation rates have been proposed as a key mechanism facilitating the survival of high-elevation low-latitude glaciers by consuming ablation energy that would otherwise be available for melting (Wagnon et al., 1999; Kaser and Osmaston, 2002). Melting occurs even in the subfreezing air temperatures of KG (Mölg et al., 2008), but only on clear-sky days during short-term hygric optima with relative humidity $>90 \%$ and mean wind speed $<2.5 \mathrm{~m} \mathrm{~s}^{-1}$, which both serve to inhibit energy and mass losses through sublimation, thereby diverting energy to melting. For the rest of the time, sublimation is the dominant mode of ablation at the KG AWS and previous studies found sublimation to be responsible for two-thirds of mass loss and consumption of almost all the energy available for ablation at this site in the uppermost glacier zone (Mölg et al., 2008). This pattern of ablation and ablation energy partitioning is not observed at LG even during exceptionally clear/dry conditions that can occur in JF when sublimation rates are highest. Aside from these conditions, sublimation rates at LG are low, and melting, which usually occurs during periods of positive air temperatures, is responsible for $85 \%$ of the surface ablation. As conditions at EG are more similar to those at LG than at KG, it can be expected that ablation of the glaciers in the Rwenzoris is also dominated by melt rather than sublimation. In addition, the lack of any marked dry season will further limit the importance of sublimation in the Rwenzoris. All the South American AWS sites are situated in the glacier ablation zones, where melting is responsible for 96, 98, and $84 \%$ of surface ablation at AG, ARG, and ZG, respectively (Favier et al., 2004a; Juen, 2006). The partitioning of ablation energy consumed by sublimation between the warm/wet (14\%) and clear/dry (88\%) extreme conditions at LG AWS is comparable to that found for the typical wet (10-15\%) and dry (60-90\%) seasons in the ablation zone of ARG (Winkler et al., 2009). Turbulent energy fluxes at $Z G$ are primarily 
controlled by wind speed and tend to balance each other out while at ARG, and the inner-tropical glaciers, QL is not fully offset by QS.

In the outer tropics of South America, seasonal changes in melt energy are driven by net longwave radiation (Sicart et al., 2005), which is strongly negative during the dry season and reduces the available ablation energy. At the same time, atmospheric aridity drives high rates of sublimation, which leaves little energy for melting; thus, although energy consumed by ablation is large, mass fluxes remain small (Juen, 2006; Sicart et al., 2005). At ARG, sublimation during dry conditions increases surface ice albedo (Juen, 2006), thus further reducing the energy flux to the surface by limiting net shortwave radiation flux in the ablation zone during periods when potential SWI is high in clear-sky conditions. At LG, although the net longwave does vary throughout the year, this is more than compensated for by concurrent changes in the net shortwave, and the correlation analysis indicates that melt energy is more influenced by the shortwave than the longwave component of the radiation fluxes. The seasonal variation in sublimation rate is a feature common to all sites, and even slight shifts in humidity between seasons are consequently amplified in the surface energy flux partitioning. At AG, sublimation is essentially limited to the drier and windier JJAS period, while at LG, although sublimation occurs year round, it is most enhanced during the dry months of JF. Sublimation may serve to reduce surface mass loss during these months, but nevertheless surface melting remains high during these times, and the feedback effect of sublimation rate on ice albedo (Juen, 2006) was not evident at LG.

At $Z G$, the timing of the onset of the wet season can be important in determining the annual mass balance (Favier et al., 2004a), since prior to the wet season high SWI and low albedo following the dry season result in high melt energy potential. Comparable patterns are likely to exist at inner tropical glaciers, where the timing and duration of the rainy seasons are critical to maintaining mass during the season of potential maximum solar radiation.

\section{Conclusions}

The AWS on LG provides unique information of detailed meteorological conditions high on Mt Kenya in the equatorial mid-troposphere. Meteorological conditions at LG show little variability on an annual timescale that would be in accordance with the established regional hygric seasonality. The available data suggest contrasts in the pattern of hygric seasonality at the summit of Mt Kenya and Kilimanjaro, whereby JF (JJAS) is the more arid of the two dry seasons and OND (MAM) is the more reliable of the two wet seasons at Mt Kenya (Kilimanjaro). Specific meteorological conditions experienced on equatorial East African glaciers deviate significantly in terms of elevation-dependent offsets in radiative fluxes, air temperature, humidity and wind speed. Fur- thermore, concurrent data from Lewis and Kersten glaciers demonstrate more frequent convergence of convective clouds over the summit of Mt Kenya compared to the summit of Kilimanjaro. Differences in the amount of solid precipitation and the mean density of fresh snow indicate that up to twice as much snow accumulation can be expected at the summit of Mt Kenya as at the summit of Kilimanjaro. This, and the effect of more frequent cloud cover, which serves to reduce the net radiation flux at $\mathrm{LG}$, provides a possible explanation for glaciers remaining on Mt Kenya at a lower elevation than on Kilimanjaro.

In contrast to both the outer tropics and altitudes $>5500 \mathrm{~m}$ a.s.l. in the inner tropics, total ablation rates at LG remain high even during exceptionally clear and dry conditions, when a marked increase in sublimation does not prevent high rates of surface melting. Although wet seasons are typically periods of positive mass balance at LG, this is not reliable as (i) wet seasons can fail, and (ii) during anomalously warm conditions, as occurred in the warm/wet extreme studied here, even significant mass accumulation cannot offset the efficient removal of mass through high rates of surface melting. While the mass balance of KG on Kilimanjaro is only sensitive to solid precipitation, on Mt Kenya, correlation of melt energy with other atmospheric variables at LG indicates that mass balance variability is not driven by accumulation alone. Nevertheless, precipitation exerts the greatest control on surface energy balance by controlling the net shortwave receipts via the surface albedo, and months with positive mass balances generally only occur when total snow accumulation approaches $5 \mathrm{~kg} \mathrm{~m}^{-2} \mathrm{day}^{-1}$. In contrast to KG, at LG ablation is always dominated by melting and the energy balance conditions in the upper portion of LG are more closely comparable to those measured in the ablation zones of South American tropical glaciers. Under current conditions, summit precipitation levels are insufficient to sustain a glacier on Mt Kenya, and LG underwent strongly negative mass balance even in the upper reaches of the glacier during the measurement period, when precipitation anomalies were more frequently negative than positive in the context of the last decade.

Investigation of the clearly different convective cloud formation regimes on Mt Kenya and Kilimanjaro using limitedarea atmospheric modeling is required to resolve the influence of atmospheric stability and dynamical processes on limiting the vertical extent of convection and the convergence of clouds over the summit at Mt Kenya, and contrasts in humidity seasonality between the two summits. Existing highresolution atmospheric modeling (Mölg et al., 2009b; Mölg and Kaser, 2011) indicates that at least the former is crucial on Kilimanjaro. The climatic proxy offered by KG was determined by distributed mass balance modeling to be dominated by variability in the short rains (Mölg et al., 2009a), which is in turn an effective proxy for Indian Ocean circulation. At LG it appears unlikely that a single parameter or season will dominate the mass balance variability, and this will 
be explored in forthcoming distributed mass balance modeling of LG in order to evaluate the glacier wide mass balance sensitivity to climate conditions at this site.

Acknowledgements. This study was funded by the Austrian Science Fund (FWF grant P21288-N21). We thank Stephan Galos, Martin Kaser, Christian Lambrechts and Michael Schultz for field assistance, as well as the Mount Kenya Guides and Porters Safari Club. We also acknowledge the support of the Kenya Wildlife Service (especially Simon Gitau), the National Council of Science and Technology, the Kenya Meteorological Department and UNEP/DEWA.

Edited by: M. Van den Broeke

\section{References}

Anderson, P. S.:A method for rescaling humidity sensors at temperatures well below freezing, J. Atmos. Oc. Technol., 11, 13881391, 1994.

Bintanja, R. and Van den Broeke, M. R.: The surface energy balance of Antarctic snow and blue ice, J. Appl. Met., 34, 902-926, 1995.

Bradley, R., Keimig, F. T., Diaz, H. F., and Hardy, D. R.: Recent changes in freezing level heights in the Tropics with implications for the deglacierization of high mountain regions, Geophys. Res. Lett., 36, L17701, doi:10.1029/2009GL037712, 2009.

Braithwaite, R. J.: On glacier energy balance, ablation, and air temperature, J. Glaciol., 27, 381-391, 1981.

Brock, B.W., Willis, I. C., and Sharp, M. J.: Measurement and parameterization of aerodynamic roughness length variations at Haut Glacier d'Arolla, Switzerland, J. Glaciol., 52, 281-297, 2006.

Chan, R. Y., Vuille, M., Hardy, D. R., and Bradley, R.: Intraseasonal precipitation variability on Kilimanjaro and the East African region and its relationship to the large-scale circulation, Theor. Appl. Climatol., 93, 149-165, 2008.

Cullen, N. J., Mölg, T., Kaser, G., Hussein, K., Steffen, K., and Hardy, D. R.: Kilimanjaro Glaciers: Recent areal extent from satellite data and new interpretation of observed 20th century retreat rates, Geophys. Res. Lett., 33, L16502, doi:10.1029/2006g1027084, 2006.

Cullen, N. J., Sirguey, P., Mölg, T., Kaser, G., Winkler, M., and Fitzsimons, S. J.: A century of ice retreat on Kilimanjaro: the mapping reloaded, The Cryosphere, 7, 419-431, doi:10.5194/tc7-419-2013, 2013.

Dai, A. and Wang, J.: Diurnal and semidiurnal tides in global surface pressure fields, J. Atmos. Sci.s, 56, 3874-3891, doi:10.1175/1520-0469(1999)056<3874:DASTIG > 2.0.CO;2, 1999.

Davies, T. D., Brimblecombe, P., and Vincent, C. E.: The daily cycle of weather on Mount Kenya, Weather, 406-417, 1977.

Favier, V., Wagnon, P., and Ribstein, P.: Glaciers of the outer and inner tropics: A different behaviour but a common response to climatic forcing, Geophys. Res. Lett., 31, L16403, doi:10.1029/2004gl020654, 2004a.

Favier, V., Wagnon, P., Chazarin, J. P., Maisincho, L., and Coudrain, A.: One-year measurements of surface heat budget on the ablation zone of Antizana Glacier 15, Ecuadorian Andes, J. Geophys.
Res.-Atmospheres, 109, D18105, doi:10.1029/2003jd004359, 2004b.

Francou, B., Vuille, M., Wagnon, P., Mendoza, J., and Sicart, J. E.: Tropical climate change recorded by a glacier in the central Andes during the last decades of the twentieth century: Chacaltaya, Bolivia, $16^{\circ} \mathrm{S}$, J. Geophys. Res., 108, 4154, doi:10.1029/2002JD002959, 2003.

Francou, B., Vuille, M., Favier, V., and Caceres, B.: New evidence for an ENSO impact on low-latitude glaciers: Antizana 15, Andes of Ecuador, $0^{\circ} 28$ 'S, J. Geophys. Res., 109, D18106, doi:10.1029/2003JD004484, 2004.

Funk, C., Dettinger, M. D., Michaelsen, J. C., Verdin, J. P., Brown, M. E., Barlow, M., and Hoell, A.: Warming of the Indian Ocean threatens eastern and southern African food security but could be mitigated by agricultural development, Proc. Natl. Ac. Sci., 105, 11081-6, 2008.

Georges, C. and Kaser, G.:Ventilated and unventilated air temperature measurements for glacier-climate studies on a tropical high mountain site, J. Geophys. Res., 107, 4775, doi:10.1029/2002JD002503, 2002.

Hastenrath, S.: Diurnal Thermal Forcing and Hydrological Response of Lewis Glacier, Mount Kenya, Arch. Meteor. Geophy. A, 32, 361-373, 1983.

Hastenrath, S.: The Glaciers of Equatorial East Africa, D. Reidel, Norwell, Massachusetts, 1984.

Hastenrath, S.: Zonal Circulations over the Equatorial Indian Ocean, J. Climate, 13, 2746-2756, 2000.

Hastenrath, S.: Glaciological Studies on Mount Kenya 1971-2005, Department of Meteorology, University of Wisconsin, Madison, 2005.

Hastenrath, S.: Climatic forcing of glacier thinning on the mountains of equatorial East Africa, Int. J. Climatol., 30, 146-152, 2010.

Hastenrath, S. and Patnaik, J. K.: Radiation Measurements at Lewis Glacier, Mount Kenya, Kenya, J. Glaciol., 25, 439-444, 1980.

Hastenrath, S. and Kruss, P. D.: Greenhouse indicators in Kenya, Nature, 355, 503-504, 1992.

Held, I. and Soden, B. J.: Robust responses of the hydrological cycle to global warming, J. Climate, 19, 5686-5699, 2006.

Henne, S., Klausen, J., Junkermann, W., Kariuki, J. M., Aseyo, J. O., and Buchmann, B.: Representativeness and climatology of carbon monoxide and ozone at the global GAW station Mt. Kenya in equatorial Africa, Atmos. Chem. Phys., 8, 3119-3139, doi:10.5194/acp-8-3119-2008, 2008.

Juen, I.: Glacier mass balance and runoff in the Cordillera Blanca, Perú, PhD Thesis, Department of Geography, University of Innsbruck, Ausria, 2006.

Kaser, G.: Glacier-climate interaction at low latitudes, J. Glaciol., 47, 195-204, 2001.

Kaser, G. and Georges, C.: On the mass balance of low latitude glaciers with particular consideration of the Peruvian Cordillera Blanca, Geogr. Ann. A, 81, 643-651, 1999.

Kaser, G. and Noggler, B.: Observations on Speke Glacier, Ruwenzori Range, Uganda, J. Glaciol., 37, 313-318, 1991.

Kaser, G. and Osmaston, H. A.: Tropical glaciers, International Hydrology Series, Cambridge University Press, Cambridge, 2002.

Kaser, G., Hardy, D. R., Mölg, T., Bradley, R., and Hyera, T. M.: Modern glacier retreat on Kilimanjaro as evidence of climate change: observations and facts, Int. J. Climatol., 24, 329-339, 
2004.

Lentini, G., Cristofanelli, P., Duchi, R., Marinoni, A. N., Verza, G. I., Vuillermoz, E. L., Toffolon, R., and Bonasoni, P.: Mount Rwenzori (4750 m a.s.1., Uganda): meteorological characterization and air-mass transport analysis, Geografia Fisica E Dinamica Quaternaria, 34, 183-193, 2011.

Lyon, B. and DeWitt, D. G.: A recent and abrupt decline in the East African long rains, Geophys. Res. Lett., 39, 1-5, doi:10.1029/2011GL050337, 2012.

McGregor, G. R. and Nieuwolt, S.: Tropical Climatology: An Introduction to the Climates of the Low Latitudes, 2nd Edn., John Wiley and Sons Ltd., 1998.

McHugh, M. J.: Near-surface zonal flow and east African precipitation receipt during austral summer, J. Climate, 17, 4070-4079, 2004.

Mölg, T. and Kaser, G.: A new approach to resolving climatecryosphere relations: Downscaling climate dynamics to glacierscale mass and energy balance without statistical scale linking, J. Geophys. Res., 116, D16101, doi:10.1029/2011JD015669, 2011.

Mölg, T. and Scherer, D.: Retrieving important mass-balance model parameters from AWS measurements and high-resolution mesoscale atmospheric modeling, J. Glaciol., 58, 625-628, doi:10.3189/2012JoG11J258, 2012.

Mölg, T., Georges, C., and Kaser, G.: The contribution of increased incoming shortwave radiation to the retreat of the Rwenzori glaciers, East Africa, during the 20th century, Int. J. Climatol., 23, 291-303, 2003a.

Mölg, T., Hardy, D. H., and Kaser, G.: Solar-radiation-maintained glacier recession on Kilimanjaro drawn from combined iceradiation geometry modeling, J. Geophys. Res., 108, 1-11. doi:10.1029/2003JD003546, 2003b.

Mölg, T. and Hardy, D. R.: Ablation and associated energy balance of a horizontal glacier surface on Kilimanjaro, J. Geophys. Res., 109, D16104, doi:10.1029/2003JD004338, 2004.

Mölg, T., Renold, M., Vuille, M., Cullen, N. J., Stocker, T. F., and Kaser, G.: Indian Ocean zonal mode activity in a multicentury integration of a coupled AOGCM consistent with climate proxy data, Geophys. Res. Lett., 33, L18710, doi:10.1029/2006GL026384, 2006a.

Mölg, T., Rott, H., Kaser, G., Fischer, A., and Cullen, N. J.: Comment on "Recent glacial recession in the Rwenzori Mountains of East Africa due to rising air temperature" by Richard G. Taylor, Lucinda Mileham, Callist Tindimugaya, Abushen Majugu, Andrew Muwanga, and Bob Nakileza, Geophys. Res. Lett., 33, L20404, doi:10.1029/2006GL027254, 2006b

Mölg, T., Cullen, N. J., Hardy, D. R., Kaser, G., and Klok, E. J.: Mass balance of a slope glacier on Kilimanjaro and its sensitivity to climate, Int. J. Climatol., 28, 881-892, 2008.

Mölg, T., Cullen, N. J., Hardy, D. R., Winkler, M., and Kaser, G.: Quantifying climate change in the tropical mid troposphere over East Africa from glacier shrinkage on Kilimanjaro, J. Climate, 22, 4162-4181, 2009a.

Mölg, T., Chiang, J. C. H., Gohm, A., and Cullen, N. J.: Temporal precipitation variability versus altitude on a tropical high mountain: Observations and mesoscale atmospheric modeling, Quar. J. Roy. Meteorol. Soc., 135, 1439-1455, 2009b.

Mölg, T., Cullen, N. J., and Kaser, G.: Solar radiation, cloudiness and longwave radiation over low-latitude glaciers: implications for mass-balance modeling, J. Glaciol., 55, 292-302, 2009c.
Mölg, T., Maussion, F., Yang, W., and Scherer, D.: The footprint of Asian monsoon dynamics in the mass and energy balance of a Tibetan glacier, The Cryosphere, 6, 1445-1461, doi:10.5194/tc6-1445-2012, 2012.

Mpeta, E. J. and Jury, M. R.: Intra-seasonal convective structure and evolution over tropical East Africa, Clim. Res., 17, 83-92, 2001.

Murray, F.: On the computation of saturation vapor pressure, J. Appl. Meteorol., 6, 203-204, 1967.

Mutai, C. C. and Ward, M. N.: East African rainfall and the tropical circulation/convection on intraseasonal to interannual timescales, J. Climate, 13, 3915-3939, 2000.

Nicholson, S. E.: A review of climate dynamics and climate variability in eastern Africa, in: The limnology, climatology and paleoclimatology of the East African lakes, edited by: Johnson, T. C. and Odada, E., Gordon and Breach, Amsterdam, 25-56, 1996.

Oerlemans, J., and Knap, W. H.: A 1 year record of global radiation and albedo in the ablation zone of Morteratschgletscher, Switzerland, J. Glaciol., 44, 231-238, 1998.

Ohmura, A.: Physical basis for the temperature-based melt-index method, J. App. Meteorol., 40, 753-761, 2001.

Osmaston, H.: Glaciers, glaciations and equilibrium line altitudes on Kilimanjaro. In Mahaney, edited by: W. C., Quaternary and Environmental Research on East African Mountains, Rotterdam, 7-30, 1989.

Pepin, N. C., Duane, W. J., and Hardy, D. R.: The montane circulation on Kilimanjaro, Tanzania and its relevance for the summit ice fields: Comparison of surface mountain climate with equivalent reanalysis parameters, Glob. Planet. Change, 74, 61-75, 2010.

Platt, C. M.: Some observations on the climate of Lewis Glacier, Mount Kenya, during the rainy season, J. Glaciol., 6, 267-287, 1966.

Pohl, B. and Camberlin, P.: Influence of the Madden-Julian Oscillation on East African rainfall. I: Intraseasonal variability and regional dependency, Quart. J. Roy. Meteorol. Soc., 132, 25212539, 2006.

Prinz, R., Fischer, A., Nicholson, L., and Kaser, G.: Seventysix years of mean mass balance rates derived from recent and re-evaluated ice volume measurements on tropical Lewis Glacier, Mount Kenya, Geophys. Res. Lett., 38, L20502, doi:10.1029/2011GL049208, 2011.

Prinz, R., Nicholson, L., and Kaser, G.: Variations of the Lewis Glacier, Mount Kenya, 2004-2012, Erdkunde, 66, 255-262, 2012.

Schär, C.: Mesoscale mountains and the larger-scale atmospheric dynamics: A review, Intern. Geophys., 83, 29-42, 2002.

Sicart, J. E., Ribstein, P., Chazarin, J. P., Berthier, E.: Solid precipitation on a tropical glacier in Bolivia measured with an ultrasonic depth gauge, Water Resourc. Res, 38, 1189, doi:10.1029/2002WR001402, 2002.

Sicart, J. E., Wagnon, P., and Ribstein, P.: Atmospheric controls of the heat balance of Zongo Glacier $\left(16^{\circ} \mathrm{S}\right.$, Bolivia), J. Geophys. Res., 110, D12106, doi:10.1029/2004jd005732, 2005.

Sicart, J. E., Hock, R., and Six, D.: Glacier melt, air temperature, and energy balance in different climates: The Bolivian Tropics, the French Alps, and northern Sweden, J. Geophys. Res., 113, D24113, doi:10.1029/2008JD010406, 2008.

Sun, L., Semazzi, F. H. M., Giorgi, F., and Ogallo, L. J.: Application of the NCAR Regional Climate Model to eastern Africa 2. 
Simulation of interannual variability of short rains, J. Geophys. Res., 104, 6549-6562. doi:10.1029/1998JD200050, 1999.

Thompson, L. G. and Hastenrath, S.: Climatic ice core studies at Lewis Glacier, Mount Kenya, Zeitschrift für Gletscherkunde und Glazialgeologie, 17, 115-123, 1981.

Thompson, L. G., Mosley-Thompson, E., Davis, M. E., Henderson, K. A., Brecher, H. H., Zagorodnov, V. S., Mashiotta, T. A., Lin, P.-N., Mikhalenko, V. N., Hardy, D. R., and Beer, J.: Kilimanjaro ice core records: evidence of Holocene climate change in tropical Africa, Science, 298, 589-593, 2002.

Van den Broeke, M. R., Smeets, C. J. P. P., Ettema, J., and Munneke, P. K.: Surface radiation balance in the ablation zone of the west Greenland ice sheet, J. Geophys. Res., 113, D13105, doi:10.1029/2007JD009283, 2008.

Vuille, M., Kaser, G., and Juen, I.: Glacier mass balance variability in the Cordillera Blanca, Peru and its relationship with climate and the large-scale circulation, Global Planet. Change, 62, 1428, 2008.

Wagnon, P., Ribstein, P., Francou, B., and Pouyaud, B.: Annual cycle of energy balance of Zongo Glacier, Cordillera Real, Bolivia, J. Geophys. Res., 104, 3907-3923, doi:10.1029/1998JD200011, 1999.
Wagnon, P., Ribstein, P., Francou, B., and Sicart, J. E.: Anomalous heat and mass budget of Glaciar Zongo, Bolivia, during the 1997/98 El Niño year, J. Glaciol., 47, 21-28, 2001.

WGMS: Fluctuations of Glaciers 2000-2005, Volume IX. Haeberli, W., Zemp, M., Kääb, A., Paul, F. and Hoelzle, M. (eds.), ICSU(FAGS)/IUGG(IACS)/UNEP/UNESCO/WMO, World Glacier Monitoring Service, Zurich, Switzerland, 2008.

Whittow, J. B.: Some observations on the snowfall of Ruwenzori, J. Glaciol., 3, 765-772, 1960.

Williams, A. and Funk, C.: A westward extension of the warm pool leads to a westward extension of the Walker circulation, drying eastern Africa, Clim. Dyn., 37, 2417-2435, 2011.

Winkler, M., Juen, I., Mölg, T., Wagnon, P., Gómez, J., and Kaser, G.: Measured and modelled sublimation on the tropical Glaciar Artesonraju, Perú, The Cryosphere, 3, 21-30, doi:10.5194/tc-321-2009, 2009.

Zeng, J., Matsunaga, T., and Mukai, H.: METEX - A flexible tool for air trajectory calculation, Environ. Modell. Software, 25, 607-608, 2010. 